\title{
PP2B and ERK1/2 regulate hyaluronan synthesis of HT168 and WM35 human melanoma cell lines
}

\author{
ÉVA KATONA $^{1^{*}}$, TAMÁS JUHÁSZ ${ }^{1 *}$, CSILLA SZÚCS SOMOGYI ${ }^{1}$, TIBOR HAJDÚ ${ }^{1}$, CSABA SZÁSZ $^{2}$, \\ KÁLMÁN RÁCZ ${ }^{3}$, ENDRE KÓKAI ${ }^{4}$, PÁL GERGELY ${ }^{4}$ and RÓZA ZÁKÁNY ${ }^{1}$ \\ Departments of ${ }^{1}$ Anatomy, Histology and Embryology, ${ }^{2}$ Pathology and ${ }^{3}$ Forensic Medicine, ${ }^{4}$ Cell Biology \\ and Signalling Research Group of the Hungarian Academy of Sciences, Department of Medical Chemistry, \\ Research Centre for Molecular Medicine, Faculty of Medicine, University of Debrecen, H-4032 Debrecen, Hungary
}

Received September 28, 2015; Accepted November 5, 2015

DOI: 10.3892/ijo.2015.3313

\begin{abstract}
Hyaluronan (HA) is the major glycosaminoglycan component of the extracellular matrix in either normal or malignant tissues and it may affect proliferation, motility and differentiation of various cell types. Three isoforms of plasma membrane-bound hyaluronan synthases (HAS 1, 2 and 3) secrete and simultaneously bind pericellular HA. HAS enzymes are subjects of post-translational protein phosphorylation which is believed to regulate their enzymatic activity. In this study, we investigated the HA homeostasis of normal human epidermal melanocytes, HT168 and WM35 human melanoma cell lines and melanoma metastases. HAS2 and HAS3 were detected in all the samples, while the expression of HAS1 was not detectable in any case. Malignant tissue samples and melanoma cell lines contained extra- and intracellular HA abundantly but not normal melanocytes. Applying HA as a chemoattractant facilitated the migration of melanoma cells in Boyden chamber. The amount of HA was reduced upon the inhibition of calcineurin with cyclosporine A (CsA), while
\end{abstract}

Correspondence to: Dr Róza Zákány, Department of Anatomy, Histology and Embryology, Faculty of Medicine, University of Debrecen, Nagyerdei krt. 98, H-4032 Debrecen, Hungary

E-mail: roza@anat.med.unideb.hu

${ }^{*}$ Contributed equally

Abbreviations: CsA, cyclosporin A; dNTP, deoxynucleotide triphosphate; ECM, extracellular matrix; EDTA, ethylene diamine tetra-acetic acid; ERK, extracellular signal-regulated kinase; FBS, fetal bovine serum; FGF, fibroblast growth factor; GAG, glycosaminoglycan; HA, hyaluronic acid; HAS, hyaluronan synthase; MAPK, mitogen-activated protein kinase; PBS, phosphate-buffered saline; PBST, phosphate-buffered saline supplemented with 1\% Tween-20; PKA, protein kinase A; PKC, protein kinase C; $\mathrm{PP} 2 \mathrm{~B}$, protein phosphatase $2 \mathrm{~B}$; RHAMM, receptor for hyaluronanmediated motility; RT-PCR, reverse transcription followed by polymerase chain reaction; TBE, Tris-boric acid-EDTA

Key words: RHAMM, HAS2, HAS3, reversible phosphorylation, melanoma migration the inhibition of ERK1/2 with PD098059 elevated it in both cell lines. The signals of Ser/Thr phosphoproteins at $57 \mathrm{kD}$ were stronger after CsA treatment, while a markedly weaker signal was detected upon inhibition of the MAPK pathway. Our results suggest opposing effects of the two investigated enzymes on the HA homeostasis of melanoma cells. We propose that the dephosphorylation of HAS enzymes targeted by PP2B augments HA production, while their phosphorylation by the activity of MAPK pathway reduces HA synthesis. As the expression of the HA receptor RHAMM was also significantly enhanced by PD098059, the MAPK pathway exerted a complex attenuating effect on HA signalling in the investigated melanoma cells. This observation suggests that the application of MAPK-ERK pathway inhibitors requires a careful therapeutic design in melanoma treatment.

\section{Introduction}

Cutaneous malignant melanoma is a highly aggressive tumour originating from melanocytes situated in the stratum basale of the epidermis (1). Malignant transformation of melanocytes can be induced endogenously via genetic predisposition or by exogenous factors such as UV irradiation. In either case, alterations in the composition of pericellular matrix and/or cell surface receptor pattern could occur. It is widely accepted, that any modulation of the cell-matrix interaction may trigger changes in the activity of various signalling pathways leading to uncontrolled cellular proliferation or motility (2-4). Hyaluronic acid (HA) is a non-sulphated high-molecular-mass glycosaminoglycan (GAG) built by disaccharide units composed of $\mathrm{N}$-acetyl-glucosamine and glucuronic acid. HA is the most abundant component of the extracellular matrix either in normal or malignantly transformed tissues. Polyanionic character of HA may provide a highly hydrated, anti-adhesive pericellular matrix to malignantly transformed cells, including melanoma cells, playing a critical role in the invasion of surrounding tissues (5). Three isotypes of HA synthases (HAS) HAS1, HAS2, and HAS3 are responsible for the production of HA $(6,7)$. HAS are transmembrane molecules producing HA extruded into the extracellular space and they also connect it to the cells in the meantime. Major differences of the isoforms are in the length of the HA produced and the ease of the release (7-10). HAS1 
and HAS2 produce higher molecular mass $\left(10^{6} \mathrm{Da}\right) \mathrm{HA}$ chains forming a pericellular HA coat, while HA produced by HAS3 is shorter $\left(10^{5} \mathrm{Da}\right)(11,12)$. Besides the synthesising enzymes, pericellular HA also binds to cell surface receptors, of which CD44 is the best known, but an atypical variant of hyaladherins, RHAMM (receptor for hyaluronan mediated motility), also plays an important role in cell-HA interactions $(13,14)$. RHAMM fulfils primarily intracellular functions but may also appear in the plasma membrane, where it acts as a co-receptor for HA together with CD44. It is worth to mention, that presence of extracellular RHAMM is very frequent on highly malignant, invasive, metastatic tumour cells (15). Engagement of CD44 and RHAMM with HA can modulate motility and invasion of tumour cells (14), and may activate a great variety of signalling cascades (16). It is also known, that cells can incorporate small HA oligosaccharide particles by endocytosis (17) and intracellular HA may influence activity of various signal transduction pathways regulating proliferation, adhesion and motility either in normal or malignantly transformed cells (18-20). It has been published that a direct intracellular interaction of RHAMM and HA can activate ERK1/2 and can result in a consequent enhancement of cell proliferation (21).

Signalling elements connected to the HA homeostasis of tumour cells can be activated by reversible phosphorylation on Ser/Thr amino acid residues by several protein kinases such as PKA, classical PKCs (22) or Ras (23). It has also been reported that enzymatic activity of HAS2 and HAS3 isotypes are regulated by Ser/Thr phosphorylation (21). In contrast, little is known about the role of phosphoprotein phosphatases (PP) which can dephosphorylate the target proteins in the regulation of HA synthesis or binding of HA by cells. Calcineurin or PP2B is a $\mathrm{Ca}^{2+}$-calmodulin-dependent Ser/Thr specific PP, which is present in the majority of mammalian cells and tissues (24). The presence of PP2B in epidermis-related cells, such as keratinocytes and melanocytes was reported only few years ago $(25,26)$. Importance of PP2B in skin homeostasis is proved by the fact, that pharmacological inhibitors of this PP are applied in the dermatological practice for topic treatment of various inflammatory diseases of skin accompanied with activation of T-lymphocytes, e.g., atopic dermatitis (27). Our group has proven that calcineurin influenced migration of melanoma cells (28) but the connection of this PP and HA homeostasis has not been investigated yet.

In this study we provide evidence that unlike the melanocytes, HA is abundantly produced by melanoma cells and serves as a chemoattractant for their migration in Boyden chamber. HAS2 and HAS3 enzymes were detectable in melanoma metastases and in various human melanoma cell lines, while we failed to detect any presence of HAS1. The amount of the secreted HA can be reduced by inhibition of calcineurin with CsA, while the inhibition of ERK1/2 exerted an opposite effect. HAS3 activity was likely regulated by reversible phosphorylation controlled by PP2B and ERK1/2. We also found that inhibition of ERK1/2 activity increased the HA-guided migration of melanoma cells favouring lower molecular weight HA as a chemoattractant.

\section{Materials and methods}

Culturing melanoma and melanocyte cell lines. Human melanoma HT168 cell line (kind gift of professor József Tímár,
Semmelweis University, Hungary) was established from A2058 cell line according to its metastasis formation in immunosuppressed mice (29), while WM35 obtained from ATCC (ATCC $^{\circledR}$ CRL-1661 ${ }^{\mathrm{TM}}$, Manassas, VA, USA) originally was isolated from a primary cutaneous melanoma of radial growth phase (30). Cells were nourished with RPMI-1640 culture medium (Sigma-Aldrich, St. Louis, MO, USA) supplemented with $10 \%$ fetal bovine serum (PAA, Piscataway, NJ, USA), $4.1 \mathrm{~g} / 1$ glucose, $2 \mathrm{mmol} / 1 \mathrm{~L}$-glutamine (Gibco, Gaithersburg, MD, USA), penicillin (100 U/ml) and streptomycin $(100 \mu \mathrm{g} / \mathrm{ml})$. NHEM cell line (PromoCell GmbH, Heidelberg, Germany) was cultured in Melanocyte Medium (PromoCell $\mathrm{GmbH}$ ) according to the instructions of the manufacturer. Cells were incubated at $37^{\circ} \mathrm{C}$ in the presence of $95 \%$ air and $5 \% \mathrm{CO}_{2}$ atmosphere and $80 \%$ humidity in $25-\mathrm{cm}^{2}$ flasks (PAA Laboratories) until $-70 \%$ confluence.

Inhibition of calcineurin and ERK $1 / 2$. Activity of calcineurin and ERK1/2 was inhibited with the continuous application of $2 \mu \mathrm{M}$ cyclosporine A (CsA) (Sigma-Aldrich) (dissolved in sterile DMSO) and $5 \mu \mathrm{M}$ PD098059 (PD) (Sigma-Aldrich) (dissolved in sterile DMSO), respectively, started 2 days before confluence. DMSO was administered as vehicle-control but no alterations were shown in any of the experiments comparing with the untreated controls (data not shown).

bHABC-histochemistry and immunocytochemistry. Histological samples with melanoma metastases (mesenterial lymph node and lung lesions) as well as control tissues from healthy human bodies were collected from cadavers with the assistance of the Pathology and the Forensic Medicine Departments $(n=3)$. The study was approved by the Ethics Committee of University of Debrecen, under licence number 3244-7/2011. For morphological analysis, cell lines were cultured on rectangular cover glasses (Menzel-Gläser, Menzel $\mathrm{GmbH}$, Braunschweig, Germany). Cadaver tissue samples and cell cultures were fixed in Saint-Marie's fixative (99\% ethanol and $1 \%$ anhydrous acetic acid) for 24 or $1 \mathrm{~h}$, respectively. Tissues were embedded into paraffin and $7-\mu \mathrm{m}$ thick sections were cut. After removal of paraffin and rehydration in ethanol, PBS supplemented with $1 \%$ bovine serum albumin (BSA, Amresco LLC, Solon, OH, USA) at $37^{\circ} \mathrm{C}$ for $1 \mathrm{~h}$ was applied to block nonspecific antibody binding. HA was detected by using a biotinylated HA-binding complex in $5 \mu \mathrm{g} / \mathrm{ml}$ concentration (bHABC was kindly provided by R. Tammi and M. Tammi, Department of Anatomy, University of Kuopio, Kuopio, Finland) at $4^{\circ} \mathrm{C}$ overnight. The reaction was visualized with Streptavidin-Alexa $555(2 \mu \mathrm{g} / \mathrm{ml}$, Invitrogen Corp., Carlsbad, CA, USA) for fluorescence microscopy. Cultures and tissues were mounted in Vectashield Hard Set mounting medium (Vector Laboratories Ltd., Peterborough, UK) containing DAPI to visualise the nuclei of cells. In cadaver tissue samples, monoclonal MelanA antibody (Novocastra Laboratories Ltd., Newcastle, UK) was used to demonstrate melanin-positive cells labelling with an Alexa 488 conjugated anti-mouse antibody (Invitrogen Corporation) at a dilution 1:1,000.

For HAS2, HAS3, RHAMM and CD44 immunocytochemistry cell tissues were incubated with primary antibodies at a dilution described in Table I, at $4^{\circ} \mathrm{C}$ overnight. For visualisation of the primary antibodies Alexa Flour 488-conjugated 
Table I. The antibodies used in the experiments.

\begin{tabular}{|c|c|c|c|c|}
\hline Antibody & Host animal & $\begin{array}{c}\text { Dilution for } \\
\text { western blotting }\end{array}$ & $\begin{array}{c}\text { Dilution for } \\
\text { immunocytochemistry }\end{array}$ & Distributor; cat no. \\
\hline Anti-HAS1 & Goat, polyclonal & $1: 200$ & $1: 50$ & $\begin{array}{c}\text { Santa Cruz Biotechnology Inc., } \\
\text { Santa Cruz, CA, USA } \\
\text { sc- } 23145\end{array}$ \\
\hline Anti-HAS2 & Rabbit, polyclonal & $1: 200$ & $1: 50$ & $\begin{array}{c}\text { Santa Cruz Biotechnology Inc., } \\
\text { Santa Cruz, CA, USA } \\
\text { sc-66916 }\end{array}$ \\
\hline Anti-HAS3 & Rabbit, polyclonal & $1: 400$ & $1: 400$ & $\begin{array}{c}\text { Abcam, Camridge, UK } \\
\text { ab154104 }\end{array}$ \\
\hline Anti-HAS3 & Rabbit, polyclonal & $1: 400$ & $1: 1,000$ & $\begin{array}{c}\text { Sigma-Aldrich, St. Louis, MO, USA } \\
\text { SAB1101156 }\end{array}$ \\
\hline Anti-CD44 & Mouse, monoclonal & $1: 400$ & $1: 100$ & $\begin{array}{l}\text { Gift from: Tammi \& Tammi } \\
\text { University of Kuopio, Finland }\end{array}$ \\
\hline Anti-CD44 & $\begin{array}{l}\text { Mouse, monoclonal } \\
\text { Clone: } 2 \mathrm{C} 5\end{array}$ & $1: 400$ & $1: 100$ & $\begin{array}{c}\text { R\&D Systems, } \\
\text { Minneapolis, MN, USA } \\
\text { BBA10 }\end{array}$ \\
\hline Anti-RHAMM & $\begin{array}{l}\text { Mouse, monoclonal, } \\
\text { clone: } 2 \text { D6 }\end{array}$ & $1: 400$ & $1: 100$ & $\begin{array}{c}\text { Novocastra, Newcastle, UK } \\
\text { NCL-CD168 }\end{array}$ \\
\hline Anti- $\beta$-actin & $\begin{array}{l}\text { Mouse, monoclonal, } \\
\text { clone: AC-15 }\end{array}$ & $1: 10,000$ & - & $\begin{array}{c}\text { Sigma-Aldrich, St. Louis, MO, USA } \\
\text { A5441 }\end{array}$ \\
\hline
\end{tabular}

goat anti-rabbit (Invitrogen Corp.) and Alexa Fluor 488-conjugated goat anti-mouse (Invitrogen Corp.) secondary antibodies were used at a dilution of 1:1,000. Samples were mounted in Vectashield Hard Set mounting medium (Vector Laboratories, Ltd.) containing DAPI to visualise the nuclei of cells. Photomicrographs of the samples were taken using an Olympus DP72 camera on a Nikon Eclipse E800 microscope (Nikon Corp., Tokyo, Japan). Images were acquired using cellSense Entry 1.5 software (Olympus, Shinjuku, Tokyo, Japan) using constant camera settings to allow comparison of fluorescent signal intensities.

Migration assays in Boyden chemotaxis chamber. Cells were washed twice in CMF-PBS, harvested with $0.25 \%$ trypsin (Sigma-Aldrich) and resuspended in RPMI-1640 medium in a density of $2 \times 10^{5}$ cells $/ \mathrm{ml}$. Lower wells of 48 -well Boyden chemotaxis chamber (Neuro Probe Inc., Gaithersburg, MD, USA) were filled with human umbilical cord HA (1,600 kDa) or Streptomyces HA (300-800 kDa) (Sigma-Aldrich) dissolved in CMF-PBS at a concentration of 400 and $800 \mu \mathrm{g} / \mathrm{ml}$, respectively and covered with a polycarbonate filter (Neuro Probe Inc.) containing pores with a diameter of $3 \mu \mathrm{m}$. Cell suspension $(50 \mu \mathrm{l})$ was inoculated into the wells on the top of the membrane and the chamber was incubated for $3 \mathrm{~h}$ at $37^{\circ} \mathrm{C}$ in a humidified atmosphere $\left(5 \% \mathrm{CO}_{2}-95 \%\right.$ air). Non-migrated cells were removed from the surface of the membrane and after fixation in methanol, migrated cells were stained with $1 \%$ toluidine blue (Sigma-Aldrich) dissolved in water. Membranes were air-dried and mounted with Pertex (Sigma-Aldrich).
Absolute cell numbers were counted using a light microscope. Six-wells were counted in each experimental group and three independent assays were performed.

Measurement of cell proliferation with $\left[{ }^{3} \mathrm{H}\right]$-thymidine labelling. Medium containing $1 \mu \mathrm{Ci} / \mathrm{ml}\left[{ }^{3} \mathrm{H}\right]$-thymidine (185 GBq/mM) $\left[{ }^{3} \mathrm{H}\right]$-thymidine (American Radiolabeled Chemicals, Inc. St. Louis, MO, USA) was added to the cells cultured in wells of 24-well plates for $16 \mathrm{~h}$ after 2 days of PD treatment. After washing with PBS, proteins were precipitated with ice-cold 5\% trichloroacetic acid for $20 \mathrm{~min}$. After washing with PBS again, cells were harvested using $0.25 \%$ trypsin for $10 \mathrm{~min}$. Cells were collected with centrifugation at 2,000 rpm, the pellet was resuspended in $10 \mu \mathrm{l}$ CMF-PBS and placed into wells of special, opaque 96-well plates (Wallac, Perkin-Elmer Life and Analytical Sciences, Shelton, CT, USA). The plates were placed in an exsiccator containing phosphorous pentoxide in order to absorb moisture. Prior to the measurements, $50 \mu \mathrm{l}$ scintillation solution (MaxiLight; Hidex, Turku, Finland) was added to each well, and radioactivity was counted by a liquid scintillation counter (Chameleon Microplate Reader, Hidex). Measurements were carried out in 6 samples of each experimental group in 3 independent experiments.

RNA isolation and reverse transcriptase PCR analysis. Cell cultures were dissolved in TRIzol (Applied Biosystems, Foster City, CA, USA) and after the addition of $20 \%$ RNase free chloroform, samples were centrifuged at $4^{\circ} \mathrm{C}$ at $10,000 \mathrm{x} \mathrm{g}$ 
Table II. Nucleotide sequences, amplification sites, GenBank accession numbers, amplimer sizes and PCR reaction conditions for each primer pair are shown.

\begin{tabular}{|c|c|c|c|c|c|}
\hline Gene & Primer & Nucleotide sequence $\left(5^{\prime}-3^{\prime}\right)$ & GenBank ID & $\begin{array}{l}\text { Annealing } \\
\text { temperature }\end{array}$ & $\begin{array}{l}\text { Amplimer } \\
\text { size (bp) }\end{array}$ \\
\hline \multirow[t]{2}{*}{ HAS1 } & Sense & $\begin{array}{l}\text { CCT ACG AGG CGG TGG TCT } \\
(1261-1278)\end{array}$ & NM_001297436 & $57^{\circ} \mathrm{C}$ & 306 \\
\hline & Antisense & $\begin{array}{l}\text { GCA GAG GGA CGT AGT TAG CG } \\
(1566-1547)\end{array}$ & & & \\
\hline \multirow[t]{2}{*}{ HAS2 } & Sense & $\begin{array}{l}\text { ACA GGC ATC TCA CGA ACC } \\
(1479-1496)\end{array}$ & NM_005328 & $49^{\circ} \mathrm{C}$ & 415 \\
\hline & Antisense & $\begin{array}{l}\text { ATC TTG GCG GGA AGT AAA } \\
(1893-1876)\end{array}$ & & & \\
\hline \multirow[t]{2}{*}{ HAS3 } & Sense & $\begin{array}{l}\text { TCG GCG ATT CGG TGG ACT } \\
(835-852)\end{array}$ & NM_001199280 & $57^{\circ} \mathrm{C}$ & 280 \\
\hline & Antisense & $\begin{array}{l}\text { TGC TGG AGG AGG CTG TTG C } \\
(1114-1096)\end{array}$ & & & \\
\hline \multirow[t]{2}{*}{ RHAMM } & Sense & $\begin{array}{l}\text { AAA GTT AAG TCT TCG GAA TC } \\
(384-403)\end{array}$ & NM_001142556 & $46^{\circ} \mathrm{C}$ & 371 \\
\hline & Antisense & $\begin{array}{l}\text { CCT TCT TGC TTA GCC ATC } \\
(754-737)\end{array}$ & & & \\
\hline \multirow[t]{2}{*}{ CD44 } & Sense & $\begin{array}{l}\text { TTG TGG CAT TTA TTC ATC AG } \\
(4076-4095)\end{array}$ & NM_000610.3 & $46^{\circ} \mathrm{C}$ & 321 \\
\hline & Antisense & $\begin{array}{l}\text { GGT AGA CAG GGA GGA GCA } \\
(4396-4379)\end{array}$ & & & \\
\hline \multirow[t]{2}{*}{ GAPDH } & Sense & $\begin{array}{l}\text { CCA GAA GAC TGT GGA TGG CC } \\
(740-759)\end{array}$ & NM_002046 & $54^{\circ} \mathrm{C}$ & 411 \\
\hline & Antisense & $\begin{array}{l}\text { CTG TAG CCA AAT TCG TTG TC } \\
(1150-1131)\end{array}$ & & & \\
\hline
\end{tabular}

for $20 \mathrm{~min}$. Samples were incubated in $500 \mu \mathrm{l}$ of RNase-free isopropanol at $-20^{\circ} \mathrm{C}$ for $1 \mathrm{~h}$. After washing the centrifuged pellet by $70 \%$ ethanol the total RNA was resuspended in RNase-free water and stored at $-20^{\circ} \mathrm{C}$. The assay mixture for reverse transcriptase reaction containing $2 \mu \mathrm{g}$ RNA was performed by High Capacity RT kit (Applied Biosystems) according to the manufacturer's instructions. Amplifications were performed in a thermal cycler (Labnet MultiGene ${ }^{\mathrm{TM}}$ 96-well Gradient Thermal Cycler; Labnet International, Edison, NJ, USA) in a final volume of $25 \mu \mathrm{l}$ [containing $1 \mu \mathrm{l}$ forward and reverse primers $(0.4 \mu \mathrm{M}), 0.5 \mu \mathrm{l} \mathrm{dNTP}(200 \mu \mathrm{M})$, and $5 \mathrm{U}$ of Promega GoTaq ${ }^{\circledR}$ DNA polymerase in $1 \mathrm{X}$ reaction buffer] as follows: $95^{\circ} \mathrm{C}, 2 \mathrm{~min}$, followed by 35 cycles (denaturation, $94^{\circ} \mathrm{C}, 1 \mathrm{~min}$; annealing at optimised temperatures as given in Table II for $1 \mathrm{~min}$; extension, $72^{\circ} \mathrm{C}, 90 \mathrm{sec}$ ) and then $72^{\circ} \mathrm{C}, 10 \mathrm{~min}$. The sequences of primer pairs, and further details of polymerase chain reactions, are given in Table II. PCR products were analysed by electrophoresis in $1.2 \%$ agarose gel containing ethidium bromide. GAPDH was used as internal control. Optical density of signals was measured by Image J $1.40 \mathrm{~g}$ freeware and results were normalised to the optical density of untreated control cultures.
Preparation of total cell lysates and western blot analysis. Cell cultures were washed in physiological $\mathrm{NaCl}$ solution and then harvested. After centrifugation (2,000 rpm, $10 \mathrm{~min})$, cell pellets were suspended in $100 \mu \mathrm{l}$ of homogenization RIPA (radioimmunoprecipitation assay)-buffer $(150 \mathrm{mM}$ sodium chloride; $1.0 \%$ NP40, $0.5 \%$ sodium deoxycholate; $50 \mathrm{mM}$ Tris, $\mathrm{pH}$ 8.0) containing protease inhibitors [aprotinin $(10 \mu \mathrm{g} / \mathrm{ml})$, $5 \mathrm{mM}$ benzamidine, leupeptin $(10 \mu \mathrm{g} / \mathrm{ml})$, trypsine inhibitor $(10 \mu \mathrm{g} / \mathrm{ml}), 1 \mathrm{mM}$ PMSF, $5 \mathrm{mM}$ EDTA, $1 \mathrm{mM}$ EGTA, $8 \mathrm{mM}$ Na-Fluoride, $1 \mathrm{mM}$ Na-orthovanadate]. Samples were stored at $-70^{\circ} \mathrm{C}$. Suspensions were sonicated by pulsing burst for $30 \mathrm{sec}$ at 40 A (Cole-Parmer, Illinois, USA). For western blotting, total cell lysates were used.

Samples for SDS-PAGE were prepared by the addition of Laemmli electrophoresis sample buffer (4\% SDS, $10 \%$ 2-mercaptoethanol, $20 \%$ glycerol, $0.004 \%$ bromophenol blue, $0.125 \mathrm{M}$ Tris- $\mathrm{HCl} \mathrm{pH}$ 6.8) to cell lysates to set equal protein concentration of samples, and boiled for $10 \mathrm{~min}$. Approximately $40 \mu \mathrm{g}$ of protein was separated by $7.5 \%$ SDS-PAGE gel for detection of HAS1, HAS2, HAS3, RHAMM, CD44, and actin. Proteins were transferred electrophoretically to nitrocellulose membranes. After blocking with 5\% non-fat dry milk in 


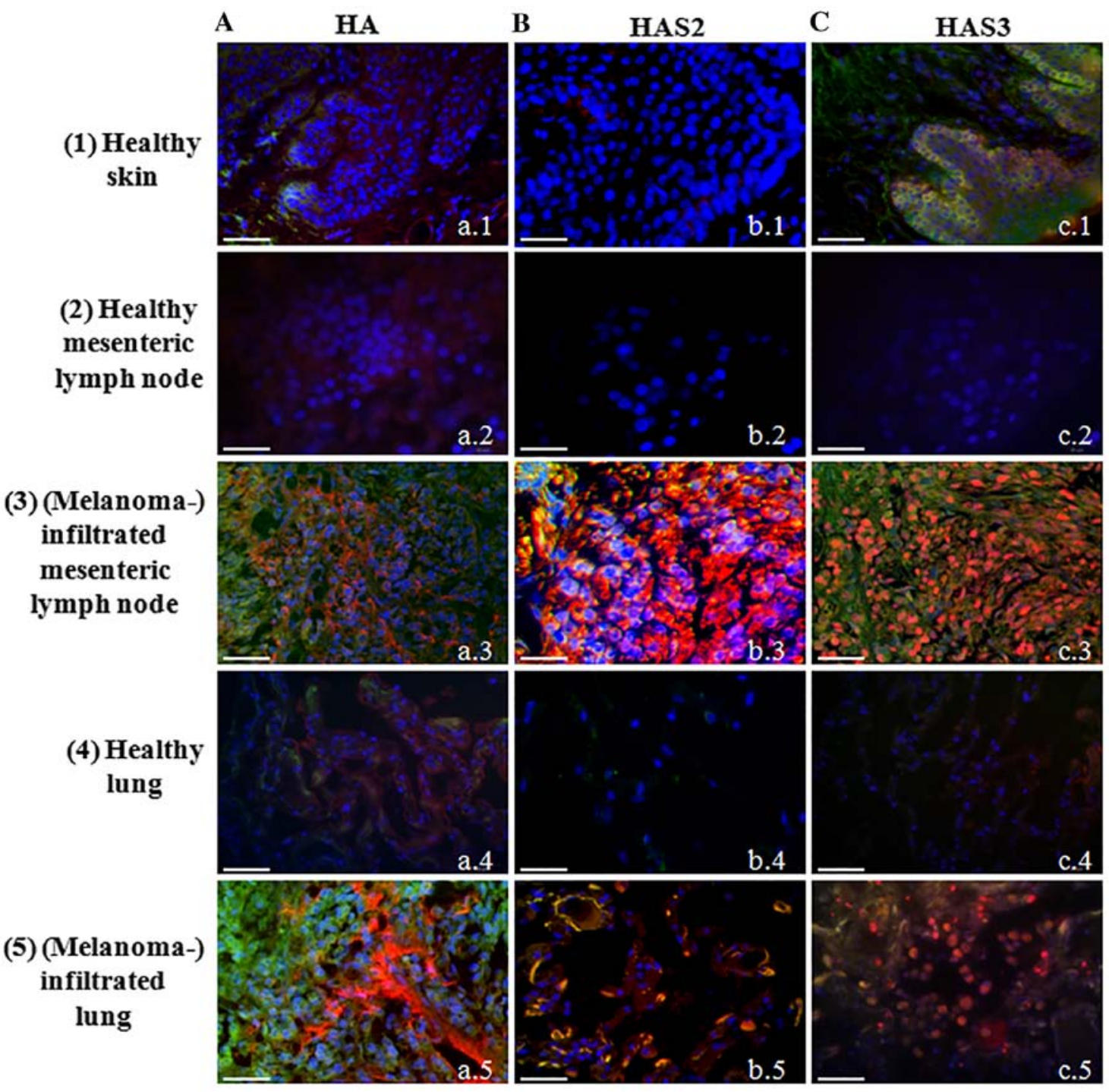

Figure 1. Detection of hyaluronic acid, HAS2 and HAS3 in normal healthy tissues and malignant metastases. Row 1, normal skin, 2, mesenteric lymph node, 3, melanoma metastasis from mesenteric lymph node, 4, normal lung, 5, melanoma metastasis from lung. (A) HA affinity histochemistry. (B) HAS2. (C) HAS3 immunohistochemistry. HA is labelled with Streptavidin-Alexa 555 (red), HAS2 and HAS3 anti-rabbit-Alexa 555 (red). Melanocytes and melanoma cells are shown with MelanA-Alexa 488 (green). Nuclei are demonstrated with DAPI (blue). Scale bar, $50 \mu \mathrm{m}$. Representative photomicrographs of 3 independent experiments are shown.

PBS, membranes were washed and exposed to the primary antibodies (Table I) overnight at $4^{\circ} \mathrm{C}$. Phospho-Ser/Thr detection kit (Millipore, Billerica, MA, USA) was used to detect phosphorylation level of Ser/Thr amino acid side chains. After washing for 3x10 min in PBST, membranes were incubated with HRP conjugated anti-rabbit IgG (Bio-Rad Laboratories, CA, USA) in 1:1,500 or anti-mouse IgG (Bio-Rad Laboratories) in 1:1,500 dilution. Signals were detected by enhanced chemiluminescence (Millipore) according to the instructions of the manufacturer. Signals were manually developed on X-ray film (Agfa-Gevaert Group, Mortsel, Belgium). Optical density of western blot signals was measured by using ImageJ $1.40 \mathrm{~g}$ freeware and the results were normalised to the values of untreated control cultures.

Statistical analysis. Optical density (OD) of RT-PCR and western blot results were normalised to the inner controls, then the ODs of the control samples of every experimental group and CsA or PD treated cultures of each melanoma cell line were used for statistical analysis. Statistical comparisons between control and test samples were performed by using Student's paired t-test where statistical method reported significant differences among the groups $(\mathrm{P}<0.05)$. The data are representative of at least three different experiments. Where applicable, data are expressed as mean \pm SEM.

\section{Results}

HA homeostasis of normal skin and melanoma metastasis. Although presence of HA around epidermal keratinocytes (31) and expression of HAS enzymes by these cells have been described long ago $(32,33)$. Involvement of melanocytes in epidermal HA homeostasis is less evident. Therefore, first we investigated the HA secretion of normal melanocytes locating in the stratum basale of human epidermis. We were able to demonstrate only a weak signal for HA in the basal cell layer 
of the epithelium (Fig. 1A-a.1). Expression of all the three HAS enzymes was also monitored. We failed to demonstrate either HAS1 (data not shown) or HAS2 in the epidermis of human skin tissue samples (Fig. 1B-b.1), but a well visible HAS3 immunopositivity was detected in the stratum basale where melanocytes reside accompanied with undifferentiated keratinocytes (Fig. 1C-c.1). As tumour invasion and motility are highly dependent on the ECM surrounding the malignant cells and HA has been proven to be one of the extracellular macromolecules which can be responsible for the regulation of infiltration of tissues in the vicinity of primary tumours (34), next we investigated HA and HAS content of melanoma samples. Two differently evolved metastases of melanoma were screened (mesenterial lymph node and lung lesions) and compared with normal tissues from healthy human cadavers. HA was modestly detectable in the normal lung and mesenteric lymph node (Fig. 1A-a.2 and a.4) but a strongly enhanced HA signal was observed either in lymph node (Fig. 1.A-a.3) or lung with melanoma metastases (Fig. 1A-a.5). HAS1 was detectable neither in normal skin, nor in malignant lesions (data not shown). The expression of HAS2 and HAS3 was not detectable with immunohistochemistry in normal lymph nodes (Fig. 1B-b.2 and c.2) or the lung (Fig. 1B-b.4 and c.4), but a strong signal of HAS2 immunopositivity was observed in lymph node melanoma metastases (Fig. 1B-b.3). In spite of the strong autofluorescence signal of elastic fibres in the lung, a well visible colocalization of HAS2 and MelanA was detected (Fig. 1B-b.5). Similarly to HAS2, HAS3 was not detected in the normal healthy tissues with this method (Fig. 1C-c.2 and c.4), but a pronounced expression was demonstrated in metastatic lymph nodes and lung metastases (Fig. 1C-c.3 and c.5). Strong HAS3 immunopositivity was seen close to the nuclei of MelanA expressing cells, as well as in the surrounding stromal cell population.

Regulation of HA secretion of in vitro melanocyte cell culture. Since the HA secretion and HAS expression were markedly altered in tissue samples with melanoma metastases we investigated the HA homeostasis of normal human melanocyte (NHEM) in a cell culture system. Similarly to the melanocytes locating in the stratum basale of epidermis, cultured melanocytes secreted only a low amount of HA, hardly detectable with affinity cytochemistry (Fig. 2A). As secretion of HA can be regulated by reversible phosphorylation, we investigated the involvement of ERK1/2 in the HA production and we also aimed to identify the involvement of a possible PP, calcineurin in this process. PD098059 was administered as a MAPK and CsA as a calcineurin inhibitor. Inhibition of PP2B activity resulted in an undetectably low HA production of cultured melanocytes (Fig. 2A). In contrast, the inhibition of ERK1/2 elevated the HA secretion of normal human melanocytes (Fig. 2A). These data suggest that the two enzymes exert the opposite effect on HA production of NHEM cells. In terms of the synthesising enzymes, mRNA of HAS1 was not present (data not shown), while the mRNAs of HAS2 and HAS3 were present in the NHEM cells (Fig. 2B), although only weak signals of protein expression were seen with western blot method (Fig. 2C). HAS2 was hardly detectable in NHEM (Fig. 2E) while HAS3 gave evident, strong signals with immunocytochemistry (Fig. 2F). Inhibition of calcineurin did not alter the mRNA expression of HAS3 and HAS2 (Fig. 2B and $\mathrm{D})$, but reduction in the protein expression of the synthases was observed (Fig. 2C-F). Inhibition of MAPK pathway exerted different effect on HAS expression of NHEM cells. It did not alter the expression of HAS2 (Fig. 2B-E), but resulted in a modest elevation of the mRNA expression (Fig. 2B and D) and a pronounced increase of the protein expression of HAS3 (Fig. 2C, D and F). Interestingly, a strong accumulation of HAS3 was visible around the nuclear area in NHEM cells after ERK1/2 inhibition (Fig. 2F).

Cells of both malignant melanoma cell lines secrete HA, but show various HAS expression patterns. It is already known that HA regulates the migration, proliferation and other cell biological features of malignant cells (5), so we aimed to detect the presence of this extracellular matrix component and to identify the HAS enzymes responsible for the production of HA in melanoma cell lines established from various stages of cutaneous melanoma.

HA was detected both intracellularly and pericellularly in the examined cell lines (Fig. 3A- $a$ and $d$ ). The detected HA is the product of HAS2 and/or HAS3 enzymes because their mRNA (Fig. 4A and C) and protein expressions (Fig. 4B and $\mathrm{D})$ were proven by reverse transcriptase PCR and western blot analyses, respectively. Neither mRNA nor protein expression of HAS1 was detected (data not shown). Similarly to NHEM, both melanoma cell lines expressed the mRNAs of both HAS enzymes (Fig. 4A) but the protein expression of the synthases showed slight differences. HAS2 protein expression was stronger in WM35 cells (Figs. 3B-a, 4B and D), while it remained weaker in HT168 cells (Figs. 3B-d, 4B and D). HAS3 protein expression showed the opposite pattern, it was stronger in HT168 cells and was almost undetectable in WM35 cells (Figs. 3C-d, 4B and D). In both cell types, HAS3 formed filamentous arrangement in the cytoplasm and positive signals associated to the nuclear region were also detected (Fig. 3C-a and d).

Inhibition of ERK1/2 and PP2B altered the HA secretion of melanoma cells. Treatment of melanoma cells with $2 \mu \mathrm{M}$ CsA notably decreased the HA secretion (Fig. 3A-b and e), while the inhibition of ERK 1/2 pathway with administration of $5 \mu \mathrm{M}$ of PD098059 increased the HA production of both cell lines (Fig. 3A-c and f). Parallel with the HA production, application of CsA also decreased HAS2 protein expression (Figs. 3B-b and e, 4B and D). Presence of the dominantly expressed HAS3 isoform of aggressive metastatic HT168 cells was significantly elevated by PD098059 treatment but no alteration was detected after the administration of CsA (Figs. 3C-c and f, 4B and D). Expression of HAS3 isoform showed only a modest decrease in WM35 cells after PP2B inhibition (Figs. 3C-b, 4B and D). At the level of $\sim 60 \mathrm{kDa}$ molecular weight we detected increased Ser/Thr phosphorylation at the presence of CsA. Administration of PD098059 exerted an opposite effect it resulted in weaker signal for phosphorylated proteins at the same molecular weight. These observations suggest altered phosphorylation and the likelihood of a consequent change in the enzymatic activity of HAS2 and/or HAS3 under the effect of the applied enzyme inhibitors (Fig. 4E and F). 


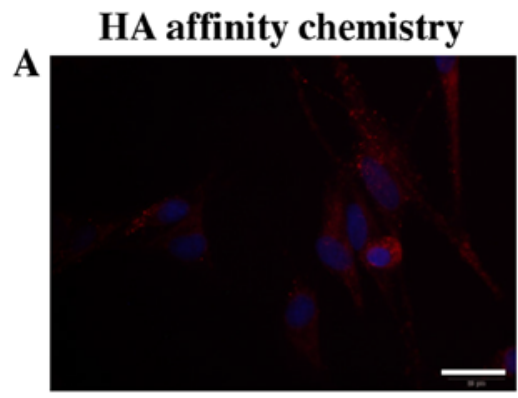

NHEM

B

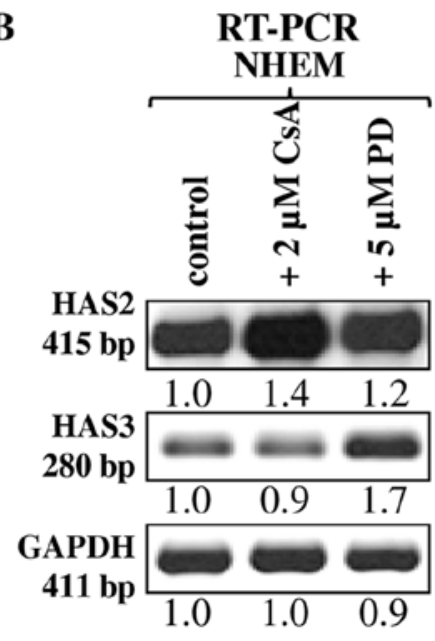

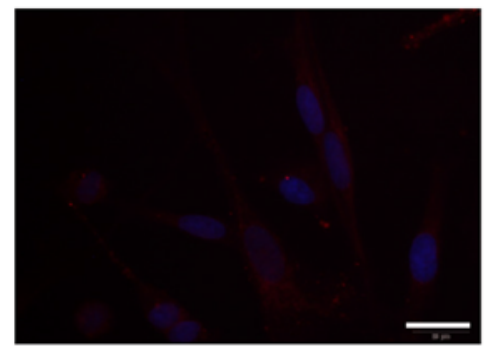

$+\operatorname{CsA}$

C

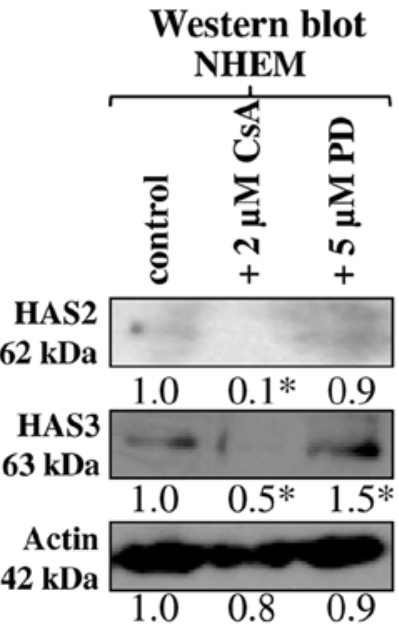

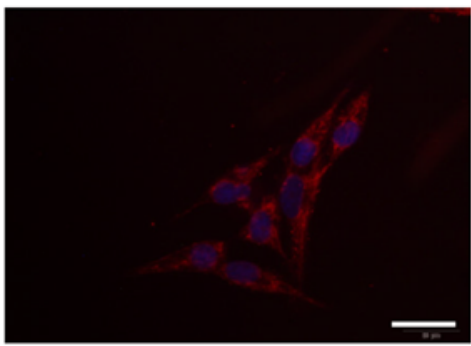

$+\mathrm{PD}$

D Statistical analysis of RT-PCR and Western blot
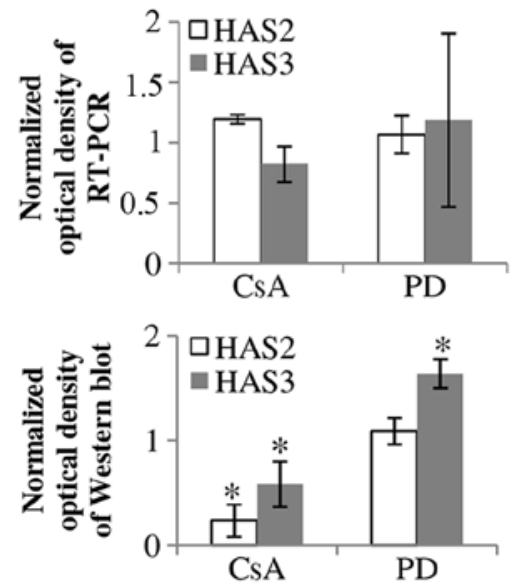

HAS2 immunocytochemistry

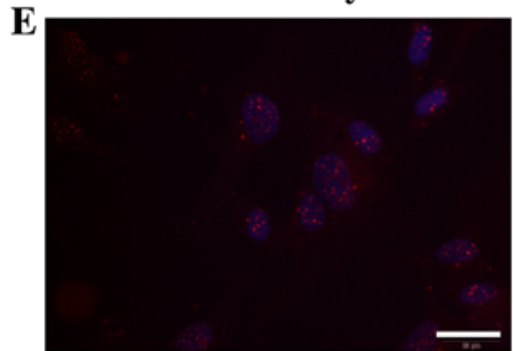

NHEM

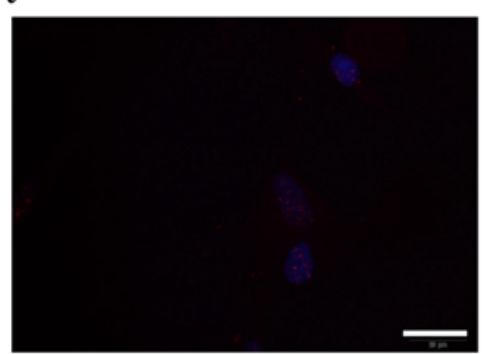

$+\mathrm{CsA}$

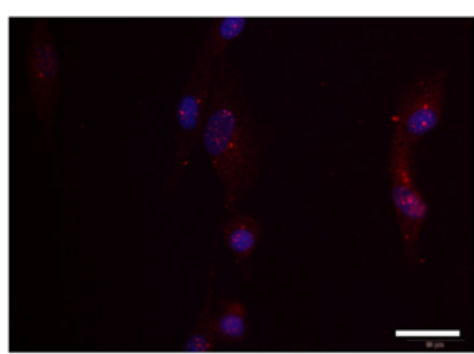

$+\mathrm{PD}$

\section{HAS3 immunocytochemistry}

$\mathbf{F}$

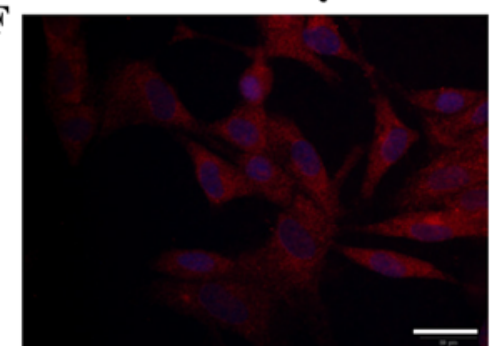

NHEM

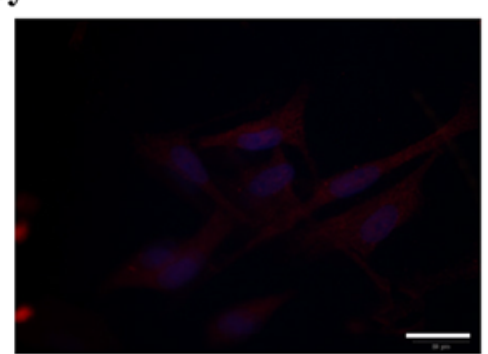

$+\mathrm{CsA}$

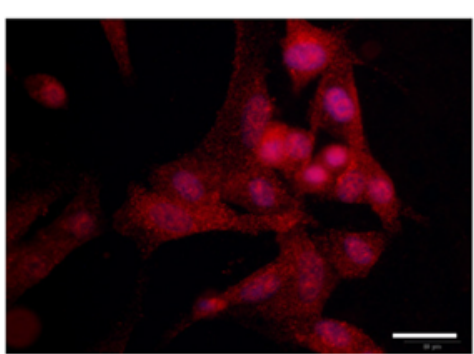

$+\mathrm{PD}$

Figure 2. Detection of HA, HAS2 and HAS3 in NHEM cells in vitro. Untreated cells of NHEM, + CsA (continuous application of CsA in $2 \mu \mathrm{M}$ ) and $+\mathrm{PD}$ (continuous application of PD098059 in $5 \mu \mathrm{M}$ ) experimental groups were performed. (A) HA affinity cytochemistry demonstrating secreted HA in red (Streptavidin-Alexa 555). Scale bar, $20 \mu \mathrm{m}$. Representative photomicrographs of 3 independent experiments. (B) mRNA expression of HAS2 and HAS3 in NHEM cells. GAPDH was used as an inner control. Representative results from three independent experiments. (C) Protein expression level of HAS2 and HAS3 in NHEM cells. Actin was used as an internal control. Representative results from three independent experiments. Optical density of signals was measured and results were normalised to the optical density of controls. In (B and C) numbers below the signals represent integrated densities of signals determined by ImageJ software. (D) Statistical analysis of RT-PCR and western blot results. All data are the average of at least three different experiments. Statistical analysis was performed by Student's t-test. The data were normalized on GAPDH or actin and are expressed as mean \pm SEM. (E and F) Immunocytochemistry of HAS2 and HAS3 appearing in red (Alexa 555). DAPI was used for visualisation of nuclei. Scale bar, $20 \mu \mathrm{m}$. Representative photomicrographs of three independent experiments. 

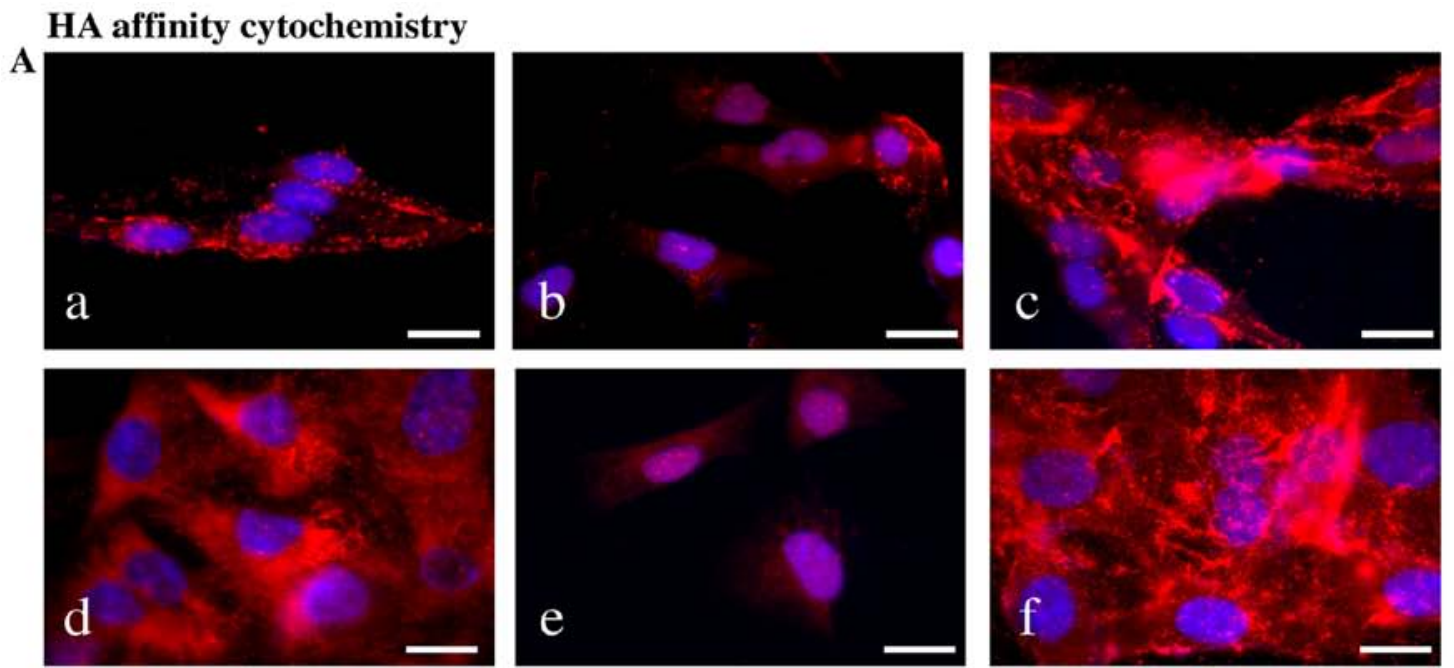

HAS2 immunocytochemistry
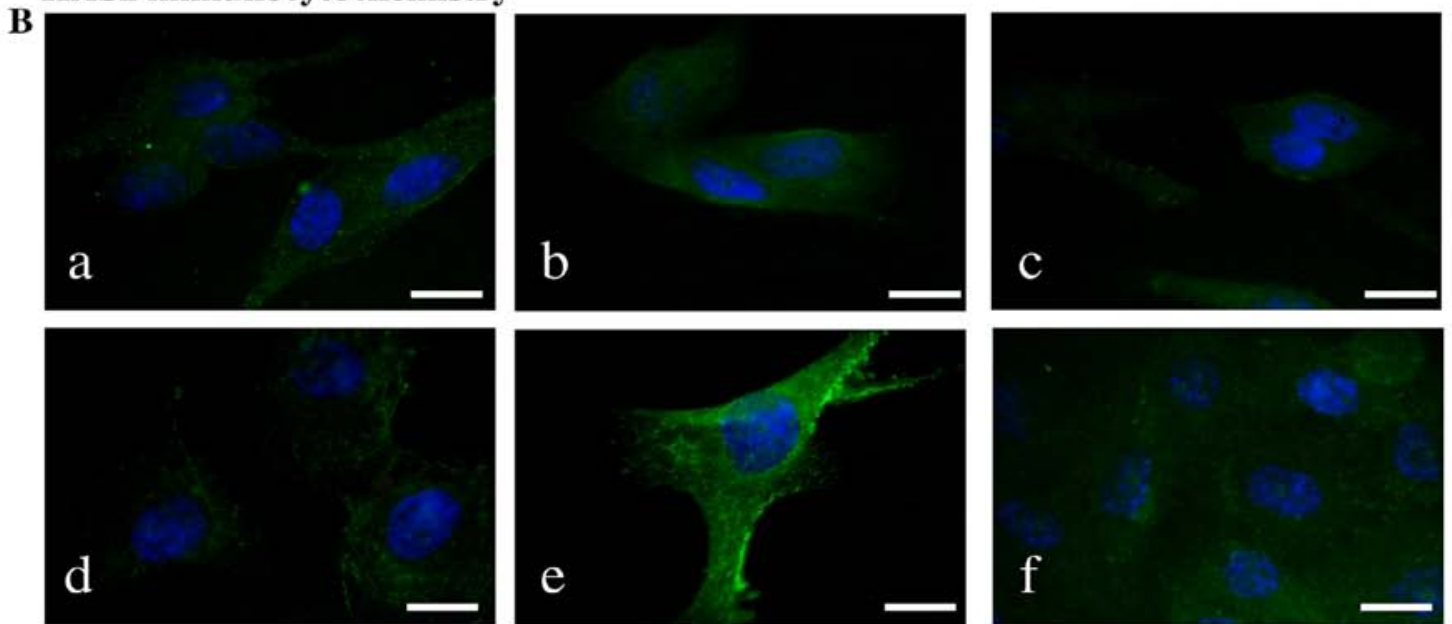

HAS3 immunocytochemistry
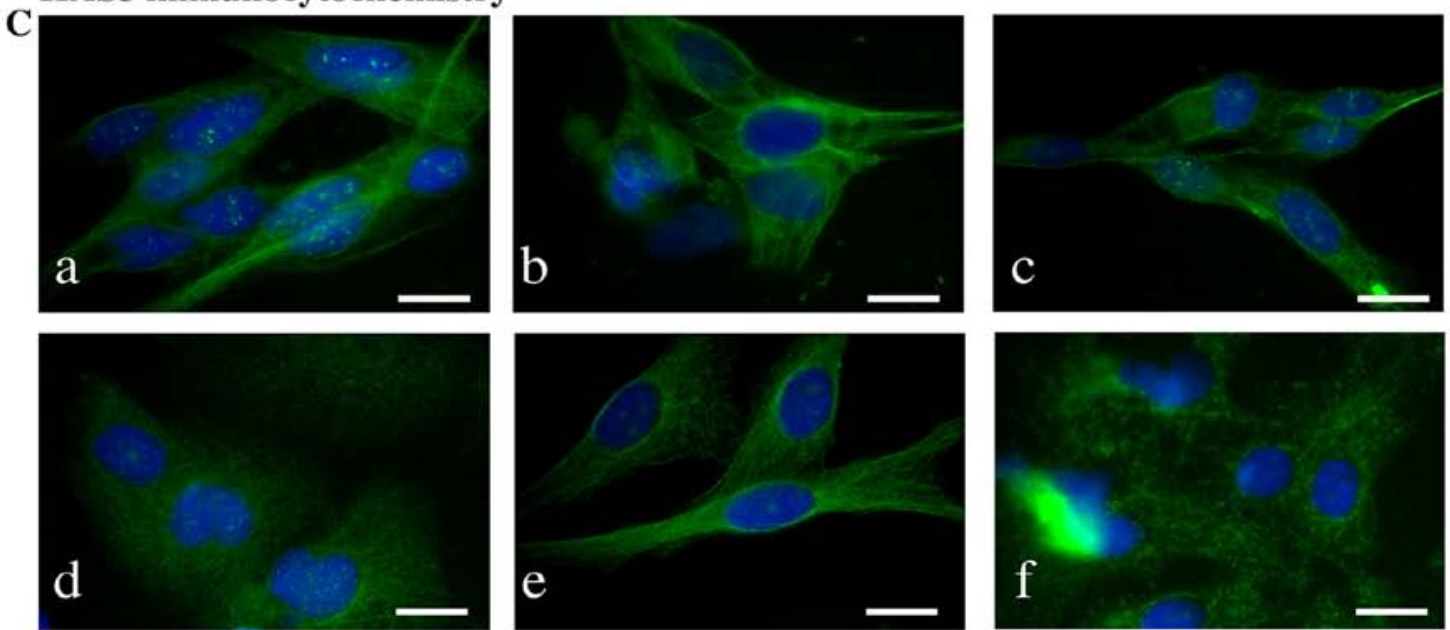

Figure 3. Detection of HA, HAS enzymes in WM35 and HT168 melanoma cell lines. (A) HA affinity cytochemistry demonstrating secreted HA in red (Streptavidin-Alexa 555). Untreated cells of WM35 (a), WM35 cells treated with $2 \mu \mathrm{M}$ of CsA (b), and with $5 \mu$ M of PD098059 (c), untreated HT168 cells (d), HT168 cells treated with $2 \mu \mathrm{M}$ of CsA (e), and with $5 \mu \mathrm{M}$ of PD098059 (f). DAPI was used for visualisation of the nuclei. Scale bar, $20 \mu \mathrm{m}$. Representative photomicrographs of 3 independent experiments. (B and C) Immunocytochemistry of HAS2 and HAS3, positive signals appear in green (Alexa 488). Untreated cells of WM35 (a), WM35 cells treated with $2 \mu \mathrm{M}$ of CsA (b), with $5 \mu \mathrm{M}$ of PD098059 (c), untreated HT168 cells (d), HT168 cells treated with $2 \mu \mathrm{M}$ of CsA (e), and with $5 \mu \mathrm{M}$ of PD098059 (f). DAPI was used for visualisation of the nuclei. Scale bar, $20 \mu \mathrm{m}$. Representative photomicrographs of three independent experiments are shown.

Involvement of receptors of hyaluronan binding in reversible dephosphorylation. It has been published that both CD44 and RHAMM have important roles in the signal transduction of melanoma cells (35). In vitro, both of these receptors can 
A

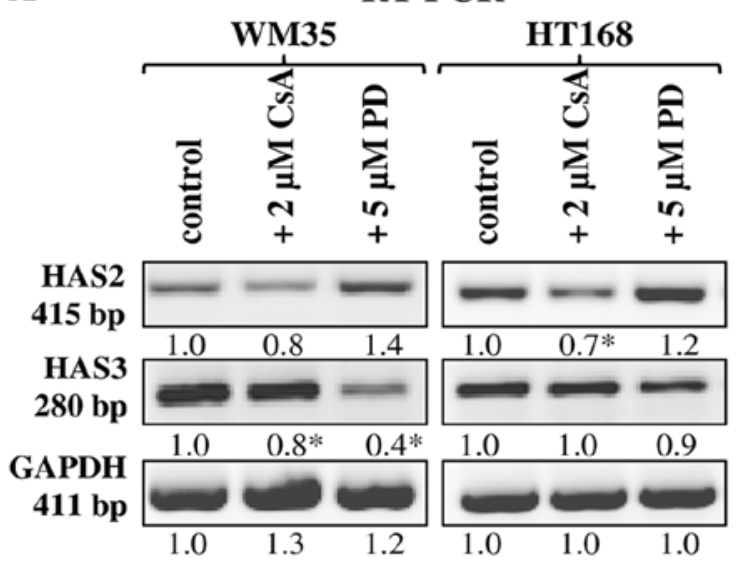

C

Statistical analysis of RT-PCR

D

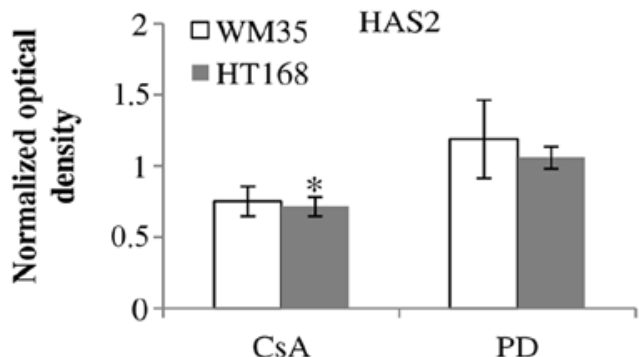

Statistical analysis of Western blot

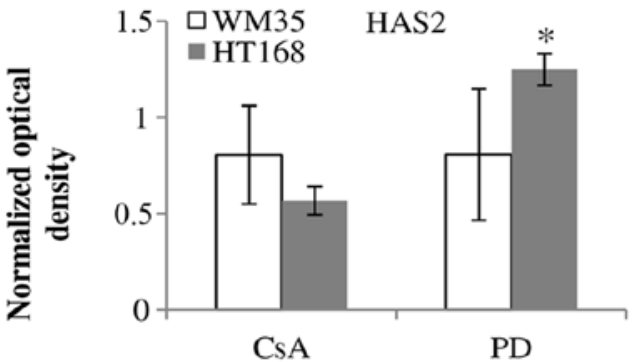

$\mathbf{E}$

Phospho Ser/Thr detection WM35 HT168
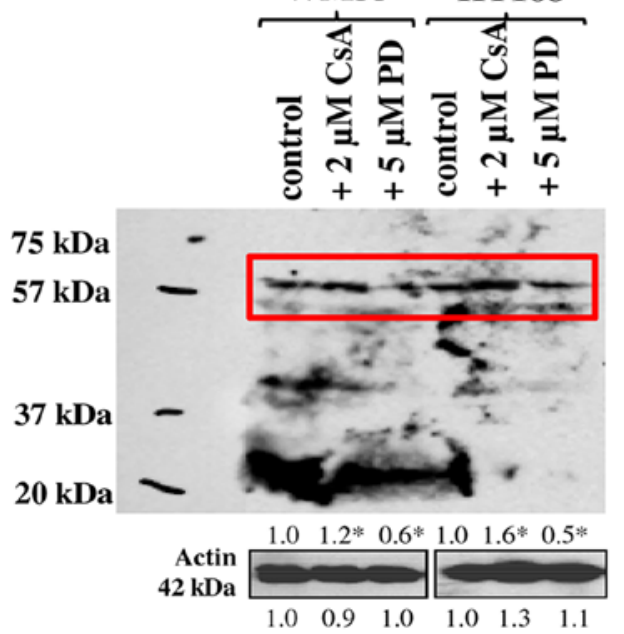

B

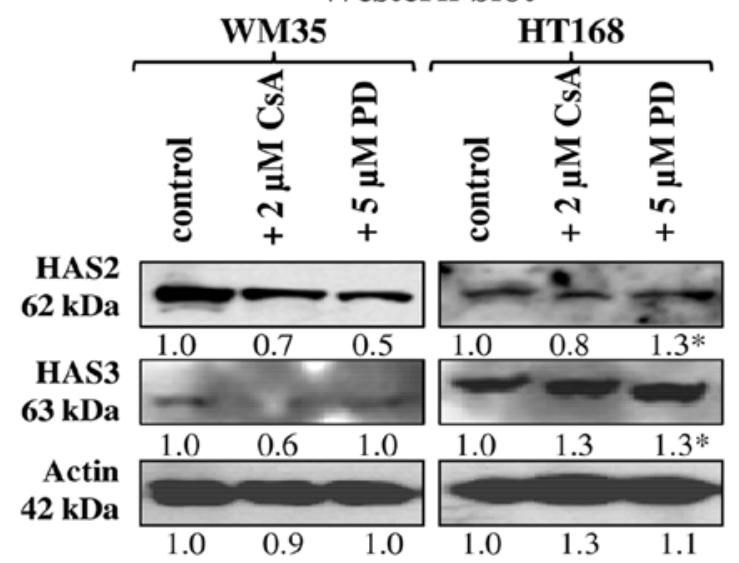

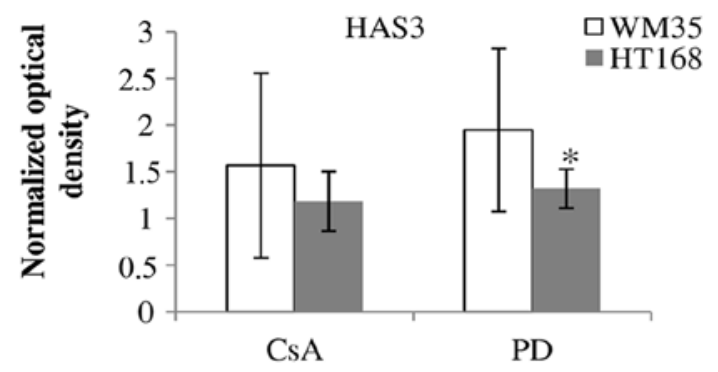

F Statistical analysis of PSer/Thr detection

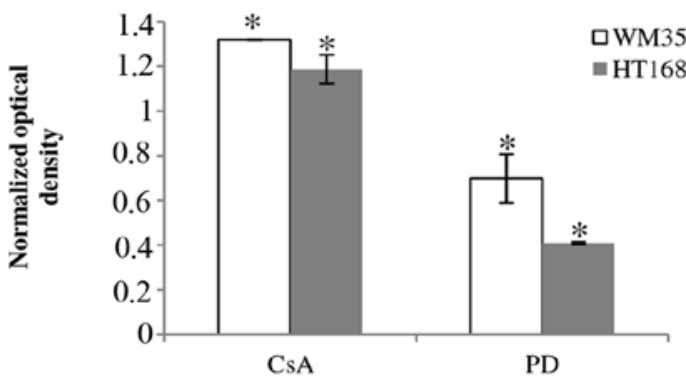

Figure 4. Detection of HAS enzyme expression and protein phosphorylation in WM35 and HT168 melanoma cell lines. (A) mRNA expression of HAS2 and HAS3 in WM35 and HT168 cells. GAPDH was used as inner control. Representative data from five independent experiments. (B) Protein expression of HAS2 and HAS3 in WM35 and HT168 cells. Representative results from five independent experiments. Actin was used as an internal control. Optical density of signals was measured and results were normalised to that of the controls. In (A and B) the numbers below signals represent integrated densities of signals determined by ImageJ software. (E) Ser/Thr phosphorylation was investigated by western blot analysis. Insert represents the signals at molecular weight of $-60 \mathrm{kDa}$. Optical density of signals was measured and results were normalised to the optical density of controls. Representative results from three independent experiments. (C, D and F) Statistical analysis of RT-PCR and western blot results. The data are the average of at least three different experiments. Statistical analysis was performed by Student's t-test. The data were normalized on GAPDH or actin and are expressed as mean \pm SEM. 

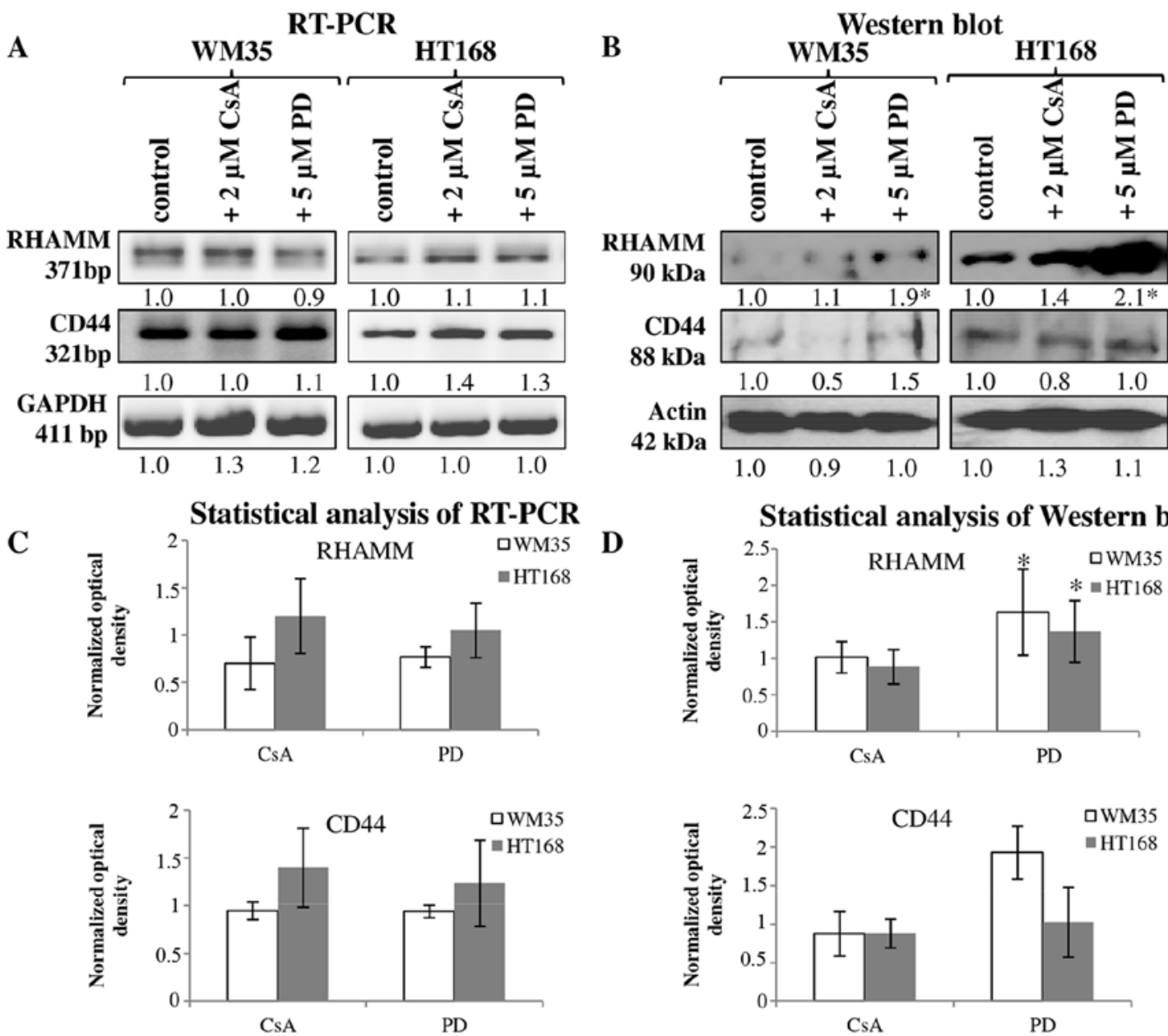

D

\section{Statistical analysis of Western blot}
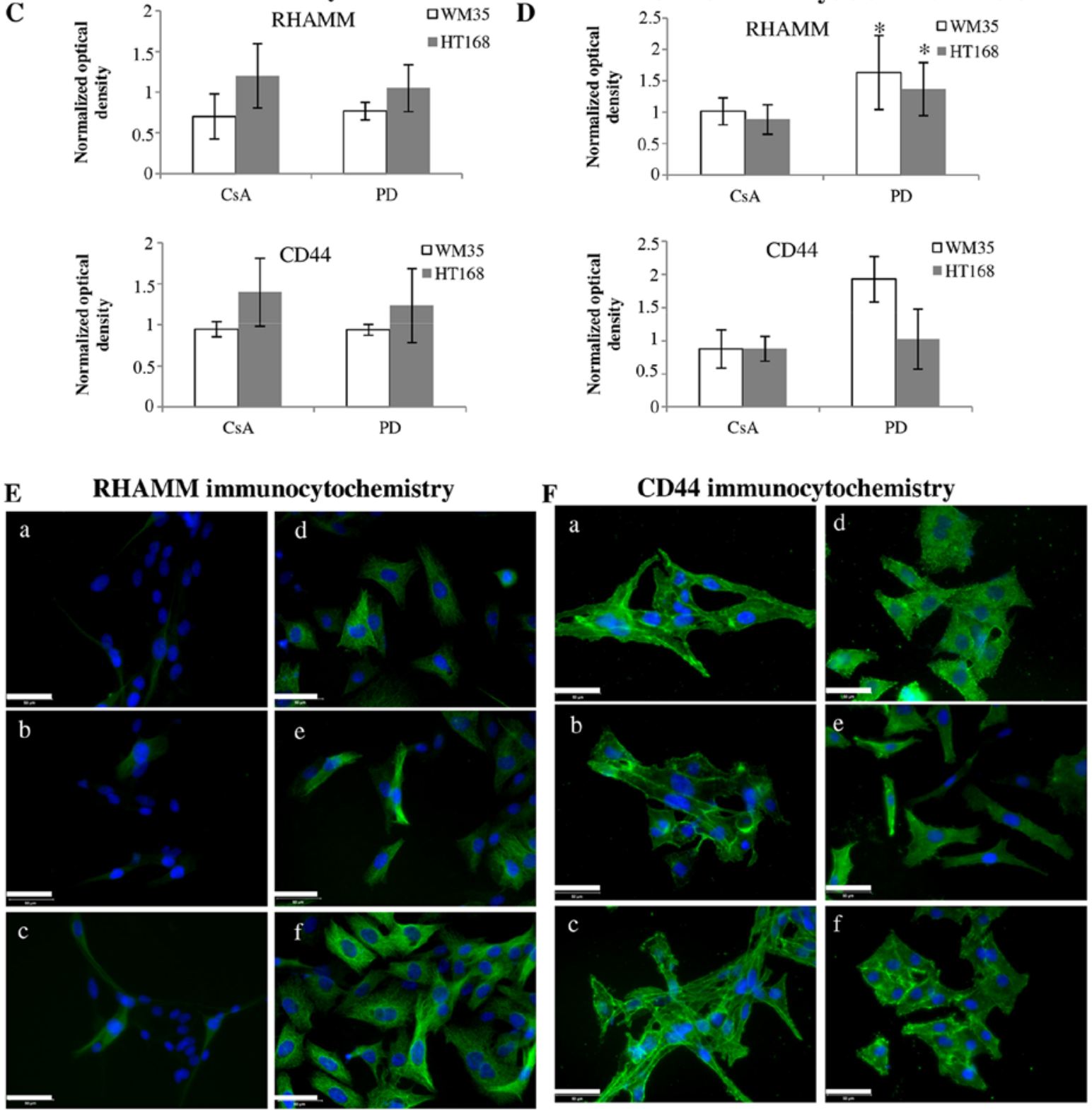

Figure 5. Investigation of the HA receptors RHAMM and CD44 in melanoma cell lines. (A) mRNA expression of RHAMM and CD44 in WM35 and HT168 cells. GAPDH was used as an inner control. Representative data of three independent experiments. (B) Protein expression of RHAMM and CD44 in WM35 and HT168 cells. Representative results from three independent experiments. Actin was used as an internal control. (C and D) Statistical analysis of RT-PCR and western blot results. All data are the average of at least three different experiments. Statistical analysis was performed by Student's t-test. All data were normalized on GAPDH or actin and are expressed as mean \pm SEM. (E and F) Immunocytochemistry of RHAMM (E) under normal culture conditions of WM35 cells (a), after treatment with $2 \mu \mathrm{M}$ of CsA (b), and $5 \mu \mathrm{M}$ of PD098059 (c). Immunocytochemistry of CD44 (F) during normal culture conditions of HT168 cells (d), after treatment with $2 \mu \mathrm{M}$ of CsA (e), and $5 \mu \mathrm{M}$ of PD098059 (f). DAPI was used to visualise the nuclei of the cells. Scale bar, $50 \mu \mathrm{m}$. 


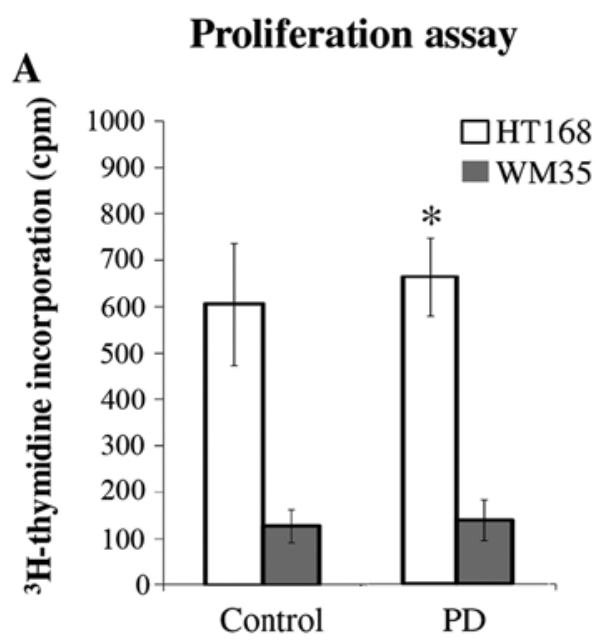

\section{Migration of WM35 cells after CsA and PD treatment}

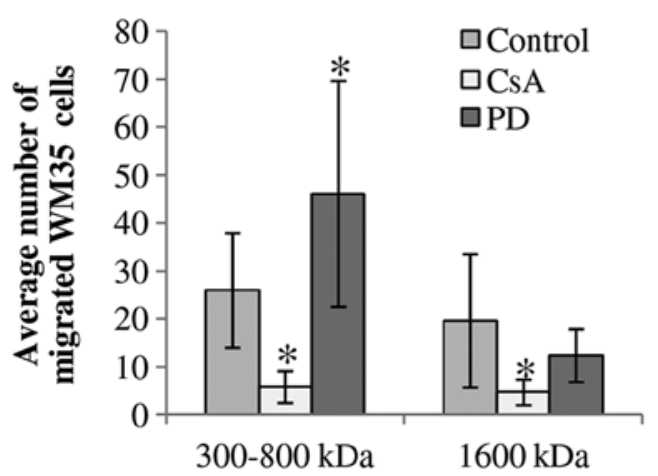

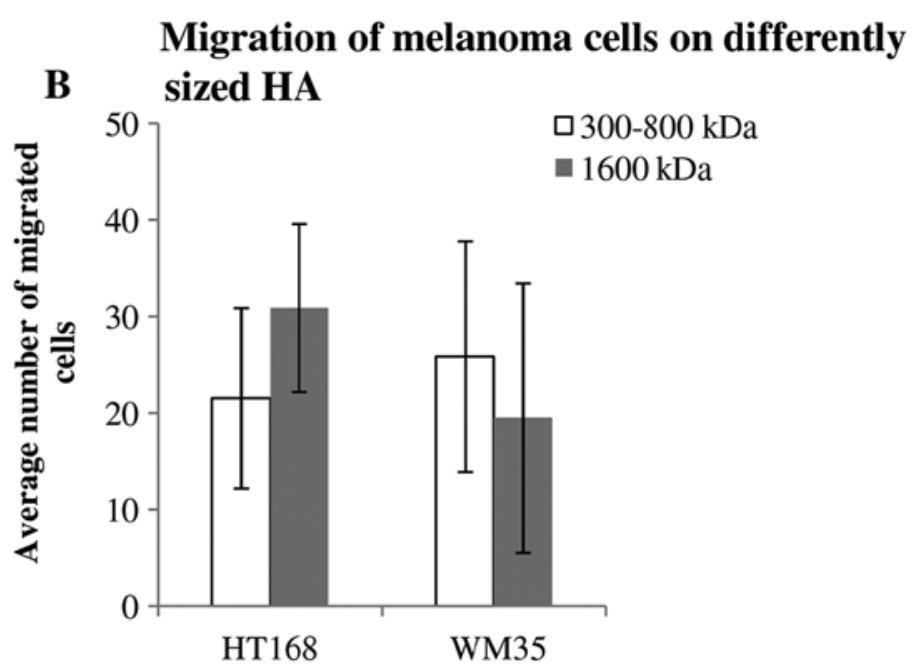

\section{Migration of $\mathrm{HT168}$ cells after CsA and PD treatment}

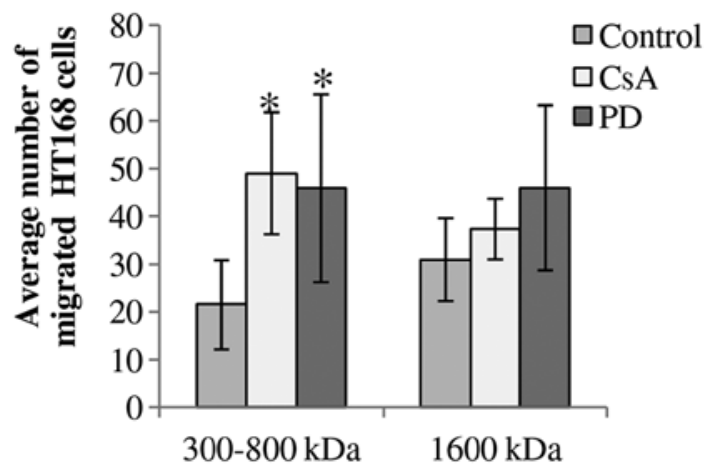

Figure 6. The effect of ERK1/2 and PP2B inhibition on proliferation and migration of malignant cells. (A) Proliferation activity was assessed by [ $\left.{ }^{3} \mathrm{H}\right]$-thymidine incorporation, applied on the second day of continuous PD098059 treatment. Data represent mean \pm standard error of the average of three independent experiments. Asterisk indicates significant $\left({ }^{*} \mathrm{P}<0.05\right)$ increase in $\left[{ }^{3} \mathrm{H}\right]$-thymidine incorporation as compared to the respective control. (B-D) Migration of different melanoma cell lines. Data represent mean \pm standard error of the mean/average of 6 independent wells and presented in the average cell number of migrated cells. Representative data of 3 independent experiments. Asterisks indicate significant $\left({ }^{*} \mathrm{P}<0.05\right)$ decrease/increase in the number of migrated cells as compared to the respective control.

play a role in the regulation of the migration of melanoma cell lines. Expression of mRNA and protein of RHAMM and CD44 were demonstrated in both cell lines (Fig. 5A-D). RHAMM gave strong intracellular signals and the observed filamentous organization of the positivity suggests association to cytoskeletal elements. CD44 also showed cytoplasmic positivity but membrane associated signals were also detected (Fig. 5E-a and F-a). Protein expression of RHAMM was higher in HT168 cell line than in WM35, while CD44 exhibited similar expression pattern both in HT168 and WM35 cell lines (Fig. 5B and D). Not every cell of the WM35 cells showed RHAMM positivity with immunocytochemistry (Fig. 5E-a). Administration of $2 \mu \mathrm{M}$ CsA did not significantly alter the protein expression of RHAMM in HT168 and in WM35 melanoma cells (Fig. 5B, D and E-b and e). In contrast, the application of $5 \mu \mathrm{M}$ PD098059 intensely elevated the protein expression of RHAMM (Fig. 5B, D and E-c and f). Furthermore, none of the inhibitors had prominent effect on the CD44 protein expression (Fig. 5B, D and F).
Intra- and/or extracellular function of secreted HA. Since incorporated HA can be partly responsible for the regulation of proliferation of tumour cells (5) we investigated the effects of inhibitors on cellular division of WM35 and HT168 melanoma cells. We have previously published results that CsA reduces the proliferation of both cell lines (28). In contrast, PD098059 elevated the proliferation rate of HT168 cells (Fig. 6A).

As strong HA signals localized in the pericellular matrix of melanoma cells either in the melanoma cell cultures or in the tissue samples containing melanoma metastases, a supportive effect of HA on cell motility seemed very likely (5). Hence, we investigated the migratory properties and invasiveness of HT168 and WM35 melanoma cell lines. An in vitro migration assay was performed in Boyden chamber in the presence of hyaluronic acid (a higher, 1,600 kDa and a lower, 300-800 kDa molecular weight HA solution) as a chemoattractant. We did not find significant differences between the migrations of these cell lines towards different 
size HA chemoattractants (Fig. 6B). As a result of the $2 \mu \mathrm{M}$ CsA or $5 \mu \mathrm{M}$ PD098059 treatments, the average number of the migrated HT168 cells toward lower molecular weight of HA was elevated but no significant alteration was shown in the presence of 1,600 kDa HA (Fig. 6D). While the administration of CsA markedly diminished the migration of WM35 cells, the presence of PD098059 significantly facilitated the migration toward 300-800 kDa HA (Fig. 6C). In contrast, cell motility in the presence of the $1600 \mathrm{kDa} H A$ was not significantly altered by PD098059 administration (Fig. 6C).

\section{Discussion}

Melanoma is one of the most aggressive and rapidly invading tumours with the worst prognosis in clinical dermatology. Formation of metastasis of malignantly transformed melanocytes is highly dependent on the cell surface receptor composition and any alterations in the composition and/or organization of the pericellular matrix (2-4). Presence of HA at the vicinity of keratinocytes has been proved in human skin (36) and its function in the metastasis formation during melanoma progression has also been demonstrated (5,37). Accumulation of HA and the activation of HA synthases during skin injury (31) or by keratinocyte growth factor (38) play a crucial role in the reconstruction of the integrity of epidermis and the subsequent tissues. Different molecular sized HA was produced by each of the HAS1, -2 and -3 , proven to exert diverse effects on the normal life cycle of cells and can influence invasiveness of malignant cells (39). The altered expression of each HAS has been published in different stages of melanoma and HA accumulation surrounding primer tumours was also detected (37). In the present study, we proved the presence of HA and HAS3 in the MelanA positive melanocytes along with a weak expression of HAS2 in the stratum basale of the normal epidermis. In contrast to the data published (37), we found elevated HA, HAS2 and also HAS3 expression but did not detect any HAS1 in malignant lesions such as lung and mesenteric lymph node metastases. The lack of HAS1 enzyme can be a result of metabolic differences of the three HAS enzymes, as HAS1 requires higher concentration of HA precursors (40). Nonetheless, abundant expression and prognostic correlation with the presence of HAS1 was found in case of breast cancer (41). Some studies indicated that inhibition of HA synthesis and accumulation of HA in the cell coat with 4-methyl-umbelliferion can also diminish migration of some type of tumour cells such as BF16 melanoma cell lines while it has no effect on other malignant cells such as breast cancer cells (42). These observations may reflect on differences in the enzymatic source of the HA-rich pericellular matrix in various malignancies. There are data demonstrating, that overexpression of HAS3 results in increase of cell surface HA and enhances cell locomotion (43) and mutations and aberrant splicing of HAS may alter the migration of tumour cells (18). Clearly, the regulation of the HA production by various HAS enzymes in different malignant tissues is an important factor which should have a deep impact on the behaviour of malignant cells. Therefore, we investigated the molecular regulation of HA synthesis focusing on Ser/Thr phosphorylation of HAS enzymes.

HA stimulates migration of melanoma cell lines in vitro via the interaction with CD44 and RHAMM (44-46). A variety of signalling pathways have been identified which associate with RHAMM (47-51) and CD44 (52-54). CD44 phosphorylation is one of the most important posttranscriptional modifications in the activation of cell-cell or cell-matrix interactions during migration (14). Another HA receptor, RHAMM regulates signalling cascades which are linked to the MAP kinase pathway, whose Ser/Thr specific protein kinase elements can be mutated in melanoma cells (55). ERK1/2 regulates proliferation of cancer cells (56) via a direct contact formed with the RHAMM-HA complex $(15,16)$. Thus, the HA induced signal transduction and ERK have a well-defined role in tumour progression, but only sporadic data exist in connection with HA synthases. It has been proven that HAS2 can be Ser/ Thr phosphorylated which may modify the HA synthesis of cells (57). As ERK1/2 has an indirect link to HA homeostasis via RHAMM binding, and it could be a question of interest whether this RHAMM-HA-ERK1/2 complex has any effect on HA synthesis (58). We found that the inhibition of ERK1/2 increased the secreted HA and elevated the expression of HAS3 in melanoma cell cultures. A similar phenomenon was described in a synoviocyte cell culture system (59). We also demonstrated, that ERK1/2 inhibition reduced the Ser/Thr phosphorylated proteins at the molecular weight of $60 \mathrm{kDa}$, which suggests that HAS2 and/or HAS3 can be targets of ERK signalling. It was an interesting phenomenon that HAS3 immunopositivity showed a filamentous organization and signals also appeared close to the nuclear area of the cells in melanoma cell lines. NHEM cells showed a strong accumulation of HAS3 around the nuclear area after the inhibition of ERK1/2. These findings strengthen the idea that ERK signalling pathways play role in the regulation of HA synthases (58) and suggest that MAPK-signalling may influence the intracellular localization of HAS enzymes, particularly HAS3. Another interesting finding was that the ERK inhibition enhanced migration towards smaller HA. As HAS3 produces lower molecular weight $\mathrm{HA}$, this observation further strengthens the probability of the functional link of ERK1/2 and this isoform of HAS (60). Smaller HA (40-70 kDa) can be incorporated to cells by endocytosis (17) and enhances proliferation, thus the increased level of HA after ERK inhibition can be one of the factors that have positive effect on cellular division as well (5). Indeed, we found that upon inhibition of MAPK pathway with PD098059, proliferation of the highly aggressive HT168 cells significantly increased.

We have published that inhibition of the Ca-calmodulin dependent cellular PP, PP2B also known as calcineurin, with cyclosporine A attenuated proliferation and enhanced expression and phosphorylation of ERK1/2 in HT168 and WM35 cell lines (28). In the present study we aimed to explore if the inhibition of this PP exerts any effect on the HA homeostasis of melanoma cells. To the best of our knowledge, there are no published experimental data on the involvement of PPs in the regulation of HA synthesis so far. Here we demonstrated that the inhibition of PP2B (calcineurin), reduced the amount of HA both in NHEM and melanoma cell lines and we detected a significant increase of Ser/Thr phoshoproteins at $60 \mathrm{kDa}$, the molecular weight of HAS2 and HAS3, during administration of CsA. These observations together with our above mentioned previous findings suggest, that PP2B may influence phosphorylation of the HAS enzymes indirectly, via modulation of the 
activity of MAPK pathway. Moreover, the inverse correlation between the amount of the phosphoproteins at $60 \mathrm{kDa}$ to the detected amount of HA raise the probability that phosphorylation of HAS enzymes at the Ser/Thr residues, which are targeted either directly or indirectly by an ERK1/2-PP2B axis, have negative effect on their biosynthetic activity in the investigated melanoma cell lines. Although this hypothesis requires further experimental support, Vigetti et al (61) observed a similar phenomenon in aortic smooth muscle cells, when activation of MAPK caused phosphorylation on threonine 110 in HAS2 and enzymatic activity became markedly lowered as the consequence of this posttranslational modification (61). In contrast, we found that pharmacological inhibition of MAPK pathway enhanced HA synthesis, while Bourguignon et al reported, that ERK activation mediated serine phosphorylation increased the HA secretion by all the three HAS isoforms (62). Clearly, the site of the phosphorylation has deep impact on the activity of HAS enzymes, it can either increase or decrease it. Moreover, certain cell specific aspects of the final outcome of HAS phosphorylation should also be taken into consideration.

Expression of the HA receptors RHAMM and CD44 has been proven both in malignant melanoma and in normal melanocytes $(5,63)$. RHAMM can be in a direct interaction with intracellular HA through which it can bind to ERK1/2. Therefore, the elevation of the expression of this HA binding receptor together with the strong HA signals upon ERK inhibition in both melanoma cell lines can be factors which promote migration and/or proliferation (5). Either the HA receptor RHAMM or ERK1/2 can bind to microtubules in the cells. Both of RHAMM and HAS3 immunocytochemistry gave a sort of filamentous arrangement in the cells in our experiments, supporting the probability of RHAMM-ERK-HAS3 crosstalk in both investigated melanoma cell lines (64). The expression of HAS3 protein was significantly lower in WM35 cells which may correlate with the milder phenotype of this cell line as it was isolated from early stage of melanoma progression (65).

In conclusion, our results reflect on differences in the chemoattractant behaviour of HA with various molecular weights. Moreover, a complex regulatory mechanism via protein phosphorylation of HAS2 and HAS3 is suggested in which PP2B plays a promoting role, while MAPK pathway attenuates HA production and RHAMM protein expression in WM35 and HT168 melanoma cell lines. This latter observation may suggest that application of MAPK-ERK pathway inhibitors requires careful, personalized therapeutic design in case of melanoma patients.

\section{Acknowledgements}

The authors thank Mrs. Krisztina Bíró of the Department of Anatomy, Medical and Health Science Centre, University of Debrecen, Hungary for her skilful and excellent technical assistance and Ms. Krisztina Körmendi and Ms. Renáta Sütő medical students for their skilful help during the study. Our grateful thanks are extended to Margit Balázs, and József Tímár for providing melanoma cell lines during the initial phase of our studies. This study was supported by grants from the Hungarian Science Research Fund (OTKA-CNK80709) and by the TÁMOP-4.2.2/B-10/1-2010-0024; and TÁMOP-
4.2.2.A-11/1/KONV-2012-0025. Éva Katona was supported by TÁMOP 4.2.4. A/2-11-1-2012-0001 'National Excellence Program - Elaborating and operating an inland student and researcher personal support system' project. The project is co-financed by the European Union and the European Social Fund. Tamás Juhász was supported by Bolyai Janos Research Scholarship, Szodoray Lajos and Magyary Zoltán Funds by Hungarian Academy of Science and the European Union and the State of Hungary, co-financed by the European Social Fund in the framework of TÁMOP 4.2.4. A/2-11-1-20120001 'National Excellence Program'. Tamás Juhász and Róza Zákány were supported by GOP-1.1.1-11-2012-0197 financed by the Hungarian government and the EU.

\section{References}

1. Tsao H, Chin L, Garraway LA and Fisher DE: Melanoma: From mutations to medicine. Genes Dev 26: 1131-1155, 2012.

2. Mandalà M, Merelli B and Massi D: Nras in melanoma: Targeting the undruggable target. Crit Rev Oncol Hematol 92: 107-122, 2014.

3. Marshall JF, Nesbitt SA, Helfrich MH, Horton MA, Polakova K and Hart IR: Integrin expression in human melanoma cell lines: Heterogeneity of vitronectin receptor composition and function. Int J Cancer 49: 924-931, 1991.

4. Pocheć E, Janik M, Hoja-Łukowicz D, Link-Lenczowski P, Przybyło M and Lityńska A: Expression of integrins $\alpha 3 \beta 1$ and $\alpha 5 \beta 1$ and GlcNAc $\beta 1,6$ glycan branching influences metastatic melanoma cell migration on fibronectin. Eur J Cell Biol 92: 355-362, 2013.

5. Ahrens T, Assmann V, Fieber C, Termeer C, Herrlich P, Hofmann M and Simon JC: CD44 is the principal mediator of hyaluronic-acid-induced melanoma cell proliferation. J Invest Dermatol 116: 93-101, 2001.

6. Itano N, Atsumi F, Sawai T, Yamada Y, Miyaishi O, Senga T, Hamaguchi $\mathrm{M}$ and Kimata $\mathrm{K}$ : Abnormal accumulation of hyaluronan matrix diminishes contact inhibition of cell growth and promotes cell migration. Proc Natl Acad Sci USA 99: 3609-3614, 2002.

7. Prehm P: Hyaluronate is synthesized at plasma membranes. Biochem J 220: 597-600, 1984.

8. Brinck $\mathbf{J}$ and Heldin P: Expression of recombinant hyaluronan synthase (HAS) isoforms in CHO cells reduces cell migration and cell surface CD44. Exp Cell Res 252: 342-351, 1999.

9. Itano N, Sawai T, Yoshida M, Lenas P, Yamada Y, Imagawa M, Shinomura T, Hamaguchi M, Yoshida Y, Ohnuki Y, et al: Three isoforms of mammalian hyaluronan synthases have distinct enzymatic properties. J Biol Chem 274: 25085-25092, 1999.

10. Weigel PH, Hascall VC and Tammi M: Hyaluronan synthases. J Biol Chem 272: 13997-14000, 1997.

11. Goentzel BJ, Weigel PH and Steinberg RA: Recombinant human hyaluronan synthase 3 is phosphorylated in mammalian cells. Biochem J 396: 347-354, 2006.

12. Kuroda Y, Kasai K, Nanashima N, Nozaka H, Nakano M, Chiba M, Yoneda $M$ and Nakamura T: 4-Methylumbelliferone inhibits the phosphorylation of hyaluronan synthase 2 induced by 12-O-tetradecanoyl-phorbol-13-acetate. Biomed Res 34: 97-103, 2013.

13. Sironen RK, Tammi M, Tammi R, Auvinen PK, Anttila M and Kosma VM: Hyaluronan in human malignancies. Exp Cell Res 317: 383-391, 2011

14. Turley EA, Noble PW and Bourguignon LY: Signaling properties of hyaluronan receptors. J Biol Chem 277: 4589-4592, 2002.

15. Maxwell CA, McCarthy J and Turley E: Cell-surface and mitoticspindle RHAMM: Moonlighting or dual oncogenic functions? J Cell Sci 121: 925-932, 2008.

16. Telmer PG, Tolg C, McCarthy JB and Turley EA: How does a protein with dual mitotic spindle and extracellular matrix receptor functions affect tumor susceptibility and progression? Commun Integr Biol 4: 182-185, 2011.

17. Qiu L, Li Z, Qiao M, Long M, Wang M, Zhang X, Tian C and Chen D: Self-assembled $\mathrm{pH}$-responsive hyaluronic acid-gpoly((L)-histidine) copolymer micelles for targeted intracellular delivery of doxorubicin. Acta Biomater 10: 2024-2035, 2014. 
18. Adamia S, Pilarski PM, Belch AR and Pilarski LM: Aberrant splicing, hyaluronan synthases and intracellular hyaluronan as drivers of oncogenesis and potential drug targets. Curr Cancer Drug Targets 13: 347-361, 2013.

19. Lee JY and Spicer AP: Hyaluronan: A multifunctional, megaDalton, stealth molecule. Curr Opin Cell Biol 12: 581-586, 2000.

20. Voelcker V, Gebhardt C, Averbeck M, Saalbach A, Wolf V, Weih F, Sleeman J, Anderegg U and Simon J: Hyaluronan fragments induce cytokine and metalloprotease upregulation in human melanoma cells in part by signalling via TLR4. Exp Dermatol 17: 100-107, 2008.

21. Hatano H, Shigeishi H, Kudo Y, Higashikawa K, Tobiume K, Takata $\mathrm{T}$ and Kamata N: RHAMM/ERK interaction induces proliferative activities of cementifying fibroma cells through a mechanism based on the CD44-EGFR. Lab Invest 91: 379-391, 2011.

22. Soares AS, Costa VM, Diniz C and Fresco P: Inosine strongly enhances proliferation of human C32 melanoma cells through PLC-PKC-MEK1/2-ERK1/2 and PI3K pathways. Basic Clin Pharmacol Toxicol 116: 25-36, 2015.

23. Haydn JM, Hufnagel A, Grimm J, Maurus K, Schartl M and Meierjohann S: The MAPK pathway as an apoptosis enhancer in melanoma. Oncotarget 5: 5040-5053, 2014.

24. Rusnak F and Mertz P: Calcineurin: Form and function. Physiol Rev 80: 1483-1521, 2000

25. Dotto GP: Calcineurin signaling as a negative determinant of keratinocyte cancer stem cell potential and carcinogenesis. Cancer Res 71: 2029-2033, 2011.

26. Smit NP, Van Rossum HH, Romijn FP, Sellar KJ, Breetveld M, Gibbs S and Van Pelt J: Calcineurin activity and inhibition in skin and (epi)dermal cell cultures. J Invest Dermatol 128: 1686-1690, 2008.

27. Breuer K, Werfel T and Kapp A: Allergic manifestations of skin diseases--atopic dermatitis. Chem Immunol Allergy 91: 76-86, 2006.

28. Juhász T, Matta C, Veress G, Nagy G, Szíjgyártó Z, Molnár Z, Fodor J, Zákány R and Gergely P: Inhibition of calcineurin by cyclosporine A exerts multiple effects on human melanoma cel lines HT168 and WM35. Int J Oncol 34: 995-1003, 2009.

29. Ladányi A, Tímár J, Paku S, Molnár G and Lapis K: Selection and characterization of human melanoma lines with different livercolonizing capacity. Int J Cancer 46: 456-461, 1990.

30. Herlyn M: Human melanoma: Development and progression. Cancer Metastasis Rev 9: 101-112, 1990.

31. Tammi R, Pasonen-Seppänen S, Kolehmainen E and Tammi M: Hyaluronan synthase induction and hyaluronan accumulation in mouse epidermis following skin injury. J Invest Dermatol 124: 898-905, 2005.

32. Sugiyama Y, Shimada A, Sayo T, Sakai S and Inoue S: Putative hyaluronan synthase mRNA are expressed in mouse skin and TGF-beta upregulates their expression in cultured human skin cells. J Invest Dermatol 110: 116-121, 1998.

33. Tammi R, Ripellino JA, Margolis RU and Tammi M: Localization of epidermal hyaluronic acid using the hyaluronate binding region of cartilage proteoglycan as a specific probe. J Invest Dermatol 90: 412-414, 1988

34. Schmaus A, Klusmeier S, Rothley M, Dimmler A, Sipos B Faller $\mathrm{G}$, Thiele $\mathrm{W}$, Allgayer $\mathrm{H}$, Hohenberger P, Post $\mathrm{S}$, et al: Accumulation of small hyaluronan oligosaccharides in tumour interstitial fluid correlates with lymphatic invasion and lymph node metastasis. Br J Cancer 111: 559-567, 2014.

35. Raso-Barnett L, Banky B, Barbai T, Becsagh P, Timar J and Raso E: Demonstration of a melanoma-specific CD44 alternative splicing pattern that remains qualitatively stable, but shows quantitative changes during tumour progression. PLoS One 8: e53883, 2013.

36. Malaisse J, Bourguignon V, De Vuyst E, Lambert de Rouvroit C, Nikkels AF, Flamion B and Poumay Y: Hyaluronan metabolism in human keratinocytes and atopic dermatitis skin is driven by a balance of hyaluronan synthases 1 and 3. J Invest Dermatol 134: 2174-2182, 2014

37. Siiskonen H, Poukka M, Tyynelä-Korhonen K, Sironen R and Pasonen-Seppänen S: Inverse expression of hyaluronidase 2 and hyaluronan synthases 1-3 is associated with reduced hyaluronan content in malignant cutaneous melanoma. BMC Cancer 13: 181, 2013.

38. Karvinen S, Pasonen-Seppänen S, Hyttinen JM, Pienimäki JP, Törrönen K, Jokela TA, Tammi MI and Tammi R: Keratinocyte growth factor stimulates migration and hyaluronan synthesis in the epidermis by activation of keratinocyte hyaluronan synthases 2 and 3. J Biol Chem 278: 49495-49504, 2003.
39. Ichikawa T, Itano N, Sawai T, Kimata K, Koganehira Y, Saida T and Taniguchi S: Increased synthesis of hyaluronate enhances motility of human melanoma cells. J Invest Dermatol 113: 935-939, 1999

40. Rilla K, Oikari S, Jokela TA, Hyttinen JM, Kärnä R, Tammi RH and Tammi MI: Hyaluronan synthase 1 (HAS1) requires higher cellular UDP-GlcNAc concentration than HAS2 and HAS3. J Biol Chem 288: 5973-5983, 2013.

41. Auvinen P, Rilla K, Tumelius R, Tammi M, Sironen R, Soini Y, Kosma VM, Mannermaa A, Viikari J and Tammi R: Hyaluronan synthases (HAS1-3) in stromal and malignant cells correlate with breast cancer grade and predict patient survival. Breast Cancer Res Treat 143: 277-286, 2014

42. Edward M, Quinn JA, Pasonen-Seppänen SM, McCann BA and Tammi RH: 4-Methylumbelliferone inhibits tumour cell growth and the activation of stromal hyaluronan synthesis by melanoma cell-derived factors. Br J Dermatol 162: 1224-1232, 2010.

43. Liu N, Gao F, Han Z, Xu X, Underhill CB and Zhang L: Hyaluronan synthase 3 overexpression promotes the growth of TSU prostate cancer cells. Cancer Res 61: 5207-5214, 2001.

44. Savani RC, Cao G, Pooler PM, Zaman A, Zhou Z and DeLisser HM: Differential involvement of the hyaluronan (HA) receptors CD44 and receptor for HA-mediated motility in endothelial cell function and angiogenesis. J Biol Chem 276 36770-36778, 2001.

45. Thomas L, Byers HR, Vink J and Stamenkovic I: CD44H regulates tumor cell migration on hyaluronate-coated substrate. J Cell Biol 118: 971-977, 1992.

46. Turley EA, Austen L, Vandeligt K and Clary C: Hyaluronan and a cell-associated hyaluronan binding protein regulate the locomotion of ras-transformed cells. J Cell Biol 112: 1041-1047, 1991.

47. Du YC, Chou CK, Klimstra DS and Varmus H: Receptor for hyaluronan-mediated motility isoform $\mathrm{B}$ promotes liver metastasis in a mouse model of multistep tumorigenesis and a tail vein assay for metastasis. Proc Natl Acad Sci USA 108: 16753-16758, 2011.

48. Hall CL, Lange LA, Prober DA, Zhang S and Turley EA: pp60(c-src) is required for cell locomotion regulated by the hyaluronanreceptor RHAMM. Oncogene 13: 2213-2224, 1996.

49. Kouvidi K, Berdiaki A, Nikitovic D, Katonis P, Afratis N, Hascall VC, Karamanos NK and Tzanakakis GN: Role of receptor for hyaluronic acid-mediated motility (RHAMM) in low molecular weight hyaluronan (LMWHA)-mediated fibrosarcoma cell adhesion. J Biol Chem 286: 38509-38520, 2011.

50. Park D, Kim Y, Kim H, Kim K, Lee YS, Choe J, Hahn JH, Lee H, Jeon J, Choi C, et al: Hyaluronic acid promotes angiogenesis by inducing RHAMM-TGF $\beta$ receptor interaction via CD44-PKC $\delta$. Mol Cells 33: 563-574, 2012.

51. Zhang S, Chang MC, Zylka D, Turley S, Harrison R and Turley EA: The hyaluronan receptor RHAMM regulates extracellular-regulated kinase. J Biol Chem 273: 11342-11348, 1998

52. Hanagiri T, Shinohara S, Takenaka M, Shigematsu Y, Yasuda M, Shimokawa $\mathrm{H}$, Nagata $\mathrm{Y}$, Nakagawa $\mathrm{M}$, Uramoto $\mathrm{H}$, So T, et al: Effects of hyaluronic acid and CD44 interaction on the proliferation and invasiveness of malignant pleural mesothelioma. Tumour Biol 33: 2135-2141, 2012

53. Ohta S, Yoshida J, Iwata $\mathrm{H}$ and Hamaguchi M: Hyaluronate activates tyrosine phosphorylation of cellular proteins including focal adhesion kinase via CD44 in human glioma cells. Int J Oncol 10: 561-564, 1997.

54. Okamoto I, Kawano Y, Murakami D, Sasayama T, Araki N, Miki T, Wong AJ and Saya H: Proteolytic release of CD44 intracellular domain and its role in the CD44 signaling pathway. J Cell Biol 155: 755-762, 2001.

55. Fecher LA, Amaravadi RK and Flaherty KT: The MAPK pathway in melanoma. Curr Opin Oncol 20: 183-189, 2008.

56. Kohno M, Tanimura S and Ozaki K: Targeting the extracellular signal-regulated kinase pathway in cancer therapy. Biol Pharm Bull 34: 1781-1784, 2011.

57. Vigetti D, Viola M, Karousou E, De Luca G and Passi A: Metabolic control of hyaluronan synthases. Matrix Biol 35: 8-13, 2014.

58. Li L, Asteriou T, Bernert B, Heldin CH and Heldin P: Growth factor regulation of hyaluronan synthesis and degradation in human dermal fibroblasts: Importance of hyaluronan for the mitogenic response of PDGF-BB. Biochem J 404: 327-336, 2007.

59. David-Raoudi M, Deschrevel B, Leclercq S, Galéra P, Boumediene K and Pujol JP: Chondroitin sulfate increases hyaluronan production by human synoviocytes through differential regulation of hyaluronan synthases: Role of p38 and Akt. Arthritis Rheum 60: 760-770, 2009 
60. Törrönen K, Nikunen K, Kärnä R, Tammi M, Tammi R and Rilla K: Tissue distribution and subcellular localization of hyaluronan synthase isoenzymes. Histochem Cell Biol 141: 17-31, 2014.

61. Vigetti D, Clerici M, Deleonibus S, Karousou E, Viola M, Moretto P, Heldin P, Hascall VC, De Luca G and Passi A: Hyaluronan synthesis is inhibited by adenosine monophosphateactivated protein kinase through the regulation of HAS2 activity in human aortic smooth muscle cells. J Biol Chem 286: 7917-7924, 2011

62. Bourguignon LY, Gilad E and Peyrollier K: Heregulin-mediated ErbB2-ERK signaling activates hyaluronan synthases leading to CD44-dependent ovarian tumor cell growth and migration. J Biol Chem 282: 19426-19441, 2007.
63. Herbold KW, Zhou J, Haggerty JG and Milstone LM: CD44 expression on epidermal melanocytes. J Invest Dermatol 106: 1230-1235, 1996.

64. Tolg C, Hamilton SR, Morningstar L, Zhang J, Zhang S, Esguerra KV, Telmer PG, Luyt LG, Harrison R, McCarthy JB, et al: RHAMM promotes interphase microtubule instability and mitotic spindle integrity through MEK1/ERK1/2 activity. J Biol Chem 285: 26461-26474, 2010.

65. Tofuku K, Yokouchi M, Murayama T, Minami S and Komiya S: HAS3-related hyaluronan enhances biological activities necessary for metastasis of osteosarcoma cells. Int J Oncol 29: 175-183, 2006. 